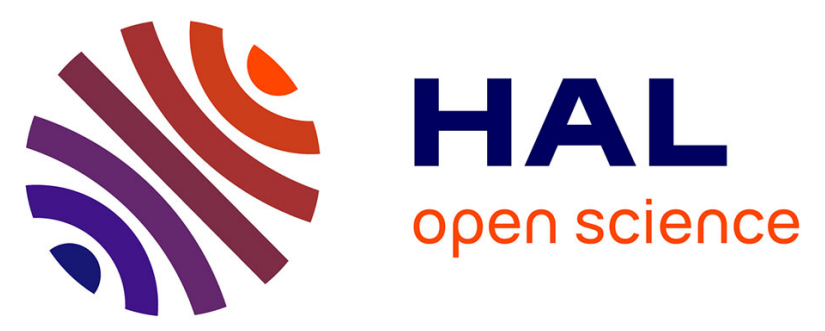

\title{
Hydrocarbon fuel synthesis from sorbitol over bifunctional catalysts: Association of tungstated titania with platinum, palladium or iridium
}

Lea Vilcocq, Amandine Cabiac, Catherine Especel, Sylvie Lacombe, Daniel Duprez

\section{To cite this version:}

Lea Vilcocq, Amandine Cabiac, Catherine Especel, Sylvie Lacombe, Daniel Duprez. Hydrocarbon fuel synthesis from sorbitol over bifunctional catalysts: Association of tungstated titania with platinum, palladium or iridium. Catalysis Today, 2015, 242, pp.91 - 100. 10.1016/j.cattod.2014.06.014 . hal01108073

\section{HAL Id: hal-01108073 \\ https://hal.science/hal-01108073}

Submitted on 22 Jan 2015

HAL is a multi-disciplinary open access archive for the deposit and dissemination of scientific research documents, whether they are published or not. The documents may come from teaching and research institutions in France or abroad, or from public or private research centers.
L'archive ouverte pluridisciplinaire HAL, est destinée au dépôt et à la diffusion de documents scientifiques de niveau recherche, publiés ou non, émanant des établissements d'enseignement et de recherche français ou étrangers, des laboratoires publics ou privés. 


\section{Hydrocarbon fuel synthesis from sorbitol over bifunctional catalysts. Association of tungstated titania with platinum, palladium or iridium}

Léa Vilcocq, ${ }^{a}$ Amandine Cabiac, $*^{a}$ Catherine Especel, ${ }^{b}$ Sylvie Lacombe ${ }^{a}$ and Daniel Duprez ${ }^{b}$ * corresponding author.

$5 \quad$ a IFP Energies nouvelles, rond-point de l'échangeur de Solaize, BP 3, 69360 Solaize, France; Tel:+33(0) 4377020 00; E-mail: amandine.cabiac@ifpen.fr; sylvie.lacombe@ifpen.fr;

vilcocq@uma.pt.

${ }^{b}$ IC2MP (Institut de Chimie des Milieux et des Matériaux de Poitiers), Université de Poitiers, UMR 10 7285 CNRS, 4 rue Michel Brunet, 86022 Poitiers Cedex, France. Fax: +33 (0) 5494539 98; Tel: +33 (0) 5494539 94; E-mail: daniel.duprez@univ-poitiers.fr; catherine.especel@univ-poitiers.fr. 


\section{Abstract}

To selectively transform sorbitol into hydrocarbons in aqueous phase, new bifunctional catalytic systems are designed by associating a hydrogenating metallic catalyst $\left(\mathrm{M} / \mathrm{ZrO}_{2}, \mathrm{M}=\mathrm{Pt}\right.$, Ir or Pd) and a 5 dehydrating acidic catalyst $\left(\mathrm{TiO}_{2}-\mathrm{WO}_{\mathrm{x}}\right)$ in a mechanical mixture. Zirconium oxide was chosen as support because it has virtually no dehydration activity and gives a good stability to the metal in water. This stability is evaluated through several characterizations before and after contact with the aqueous reaction medium. It is proposed that stability in water is driven by two parameters. The support stability is a key-parameter for the overall catalyst stability and the metal-support interaction determines the sintering extent. The nature of the metal has also an important influence on the activity and selectivity of the bifunctional $\mathrm{M} / \mathrm{ZrO}_{2}+\mathrm{TiO}_{2}-\mathrm{WO}_{\mathrm{x}}$ system for sorbitol transformation. Pd and Ir are slightly active and mainly transform sorbitol into isosorbide whereas Pt is selective for long-chain alkanes production. The mass ratio between metallic and acidic catalysts in the mechanical mixture also modifies the yields structure, with a $\mathrm{Pt} / \mathrm{ZrO} 2: \mathrm{TiO}_{2}-\mathrm{WO}_{\mathrm{x}}$ 20:80 ratio for optimal liquid hydrocarbons production.

\section{Keywords}

Aqueous Phase Dehydration/Hydrogenation (APD/H) - biofuels - iridium - palladium - platinum Sorbitol $-\mathrm{TiO}_{2}-\mathrm{WO}_{3}$ 


\section{Introduction}

To face the increasing demand for fuels, the exploitation of non-conventional supplies is necessary. One interesting alternative to oil for liquid fuels production is the use of lignocellulosic biomass as a carbon source [1-3]. Biomass is a cheap, renewable and well distributed resource. However, it contains around 50 wt.\% oxygen instead of 5 wt.\% for conventional fuels. Deoxygenating ex-biomass compounds is thus required to obtain fuels but remains a challenge. One way to reduce the oxygen content is the elimination of alcohol groups of hydrogenated sugars (i.e. polyols) in aqueous phase over bifunctional metal / acid catalysts [4-7]. Sorbitol is an interesting example of polyol because it can be easily produced from glucose by catalytic hydrogenation $[8,9]$ or directly from cellulose [1012] and is a potential source of hexane, a liquid alkane [13, 14]. Several catalytic systems have been described in the literature for sorbitol transformation [5, 7, 15-17].

Successive dehydration (on acidic sites) and hydrogenation reactions (on metallic sites) are a way to hydrodeoxygenate sorbitol into alkanes [18]. However, due to numerous intermediates and various side-reactions (decarbonylation, water gas shift and decarboxylation on metallic sites, retro-aldol condensation on basic sites), the formation of products different than alkanes is also observed: $\mathrm{CO}_{2}$, polyols, pyranic derivatives, furanic derivatives, ketones, carboxylic acids and alcohols [16, 19, 20]. A general reaction scheme illustrating this complex reaction network is presented in Figure 1. We previously studied several bifunctional catalytic systems, notably $\mathrm{Pt} / \mathrm{ZrO}_{2}$ catalyst associated with various tungstated oxides [21-23]. Tungstated titania $\left(\mathrm{TiO}_{2}-\mathrm{WO}_{\mathrm{x}}\right)$ with $14.7 \mathrm{wt} \%$ tungsten content was identified as a very active acidic phase for sorbitol transformation into C6 hydrocarbons. In the present paper, we emphasize the role of the metallic sites in sorbitol transformation. New heterogeneous catalytic systems are designed by changing the type of metal used in the metallic phase or the metal/acid phases balance. The aim is to identify an optimal metallic phase, i.e. active for sorbitol transformation, selective for hydrogenating the dehydration products formed on the acidic sites and stable under hydrothermal conditions. The selectivity criterion is crucial because the metallic sites can act as hydrogenation catalysts of $\mathrm{C}=\mathrm{O}$ or $\mathrm{C}=\mathrm{C}$ bonds formed during the dehydration reactions 
or as decarbonylation/decarboxylation catalysts, leading to C-C bond breaking (Figure 1) [22, 24, 25].

The latter reaction is undesirable because it leads to a decrease of the carbon chain length.

In this work, mechanical mixtures are prepared in order to separate the metallic phase, supported on an inert solid $\left(\mathrm{ZrO}_{2}\right)$, and the acidic phase $\left(\mathrm{TiO}_{2}-\mathrm{WO}_{\mathrm{x}}\right)$, which guarantees that the acidic sites remain unchanged when the metallic phase varies (the possible leaching/redeposition of metal on the acid phase is assumed to be insignificant). The preparation of the metallic catalysts and their stability in hydrothermal conditions are first presented. Their performances during sorbitol transformation are then depicted.

The lack of stability of several acid or bifunctional catalysts in APR or APD/H conditions has been recently reported: amorphisation of H-Y zeolites [26], hydration of $\gamma$-alumina into boehmite [27], or of silica-alumina into kaolinite [21]. The deactivation of the support is supposed to be correlated with modifications of the metallic phases. The sintering of Pt when supported on $\gamma$-alumina $[28,29]$ or on silica-alumina [21] was observed and attributed to support instability. Thus, the support of metal catalyst has to be stable in hydrothermal conditions. According to the literature, carbon supports (activated carbon, carbon black, carbon nanotubes and nanofibers), titania and zirconia are good candidates [30-33]. In this study monoclinic zirconia has been selected since it is a mesoporous oxide, allowing a good diffusion of the reactant and products, and it can be considered as non-acidic for the considered reaction.

Among the available hydrogenating metals, platinum has been chosen as a reference. Palladium and iridium have been selected for their high activity in gas phase olefin hydrogenation reactions [34]. Moreover, palladium is known for its low hydrogenolysis activity and Ir for its mono-cleaving behaviour in gas phase hydrogenolysis reaction (i.e. the selective cleavage of one C-C bond at the end of the carbon chain) [34]. Pd has been recently studied for aqueous phase hydrogenation of oxygenated compounds and showed an enhanced activity for acetaldehyde, furfural and furfuryl alcohol hydrogenation. Its activity in xylitol C-C cleavage was very low, which is interesting for our application [35].

The screening of the bifunctional catalytic system for sorbitol transformation was realized as follows: 
i) In a first step, different metallic catalysts were associated with the $\mathrm{TiO}_{2}-\mathrm{WO}_{\mathrm{x}}$ acidic phase in a similar ratio and tested. The best couple was selected.

ii) In a second step, the influence of the metal/acid phases ratio was studied for the previously selected couple.

\section{2. Experimental part}

\subsection{Catalyst preparation}

Tungstated titania was prepared by ionic exchange. $\mathrm{TiO}_{2}$ rutile (IFPEN, from literature method [36]) was used as support. $50 \mathrm{~mL}$ of $\mathrm{H}_{2} \mathrm{WO}_{4}$ in $\mathrm{H}_{2} \mathrm{O}_{2} 30 \% \mathrm{v} / \mathrm{v}$ solution $\left(0.25\right.$ mol. $\left.\mathrm{L}^{-1}\right)$ were added to $10 \mathrm{~g}$ of support dispersed in $75 \mathrm{~mL}$ water and stirred overnight. The solution was centrifuged (30 min, $8000 \mathrm{rpm})$. The recovered solid was dried $\left(80^{\circ} \mathrm{C}, 18 \mathrm{~h}\right)$ and then calcined during $3 \mathrm{~h}$ at $600^{\circ} \mathrm{C}$. The $\mathrm{TiO}_{2}-\mathrm{WO}_{\mathrm{x}}$ solid was crushed and sieved (grain size 150-355 $\mu \mathrm{m}$ ). Platinum, palladium or iridium were deposited on zirconia extrudates (MEL Chemicals) by incipient wetness impregnation using aqueous solution of $\mathrm{H}_{2} \mathrm{PtCl}_{6}$ (Alfa Aesar), $\mathrm{H}_{2} \mathrm{PdCl}_{4}$ (prepared from $\mathrm{PdCl}_{2}$, Johnson Matthey) or $\mathrm{H}_{2} \mathrm{IrCl}_{6}$ (Strem Chemicals), respectively. The amount of loaded metal was calculated to be equal to $125 \mu \mathrm{mol.g}{ }^{-1}$, i.e. $2.1 \mathrm{wt} . \%$ for Pt, $2.1 \mathrm{wt} . \%$ for Ir and $1.0 \mathrm{wt} . \%$ for Pd. The impregnated catalysts were dried at $120^{\circ} \mathrm{C}$ during $5 \mathrm{~h}$ and then calcined at $520^{\circ} \mathrm{C}, 2 \mathrm{~h}\left(\mathrm{Pt}\right.$ and $\mathrm{Ir}$ ) or $400^{\circ} \mathrm{C}, 3 \mathrm{~h}(\mathrm{Pd})$ under air flow. The catalysts were tested as extrudates in the hydrothermal stability test or milled and sieved to 150$355 \mu \mathrm{m}$ for the sorbitol transformation test. The bifunctional catalytic systems were prepared by mixing both powders $(150-355 \mu \mathrm{m})$ of the acidic and metallic catalysts in a $10 \mathrm{~mL}$ flask. The usual proportions are $4 \mathrm{~g}$ of acidic phase and $2 \mathrm{~g}$ of metallic phase, as described in previous studies [22, 23].

\subsection{Catalyst characterization}

Platinum, iridium, zirconium, titanium and tungsten contents were determined by X-ray fluorescence with a PW2404 Phillips (Panalytical). Palladium content was determined using inductively-coupled plasma (ICP-OES) with an Arcos detector. X-ray diffraction (XRD) was performed on a diffractometer from Panalytical (XPert Pro). Temperature Programmed Reduction (TPR) measurements were performed on an Autochem II920 with an $8^{\circ} \mathrm{C} \cdot \mathrm{min}^{-1}$ temperature ramp 
between $35^{\circ} \mathrm{C}$ and $1000^{\circ} \mathrm{C}$, with a $5 \% \mathrm{H}_{2} / \mathrm{Ar}$ flow. The specific BET surface area and the pore volume of the catalysts were determined by nitrogen isothermal adsorption-desorption at $-196^{\circ} \mathrm{C}$ using an ASAP 2420 (Micromeritics). Platinum and iridium dispersions were evaluated from $\mathrm{H}_{2}-\mathrm{O}_{2}$ titration in an Autochem 9500 (Micromeritics): the catalyst sample was calcined at $530^{\circ} \mathrm{C}$ under air flow and reduced at $450^{\circ} \mathrm{C}$ under hydrogen flow, then chemisorbed hydrogen was titrated by oxygen pulses at $35^{\circ} \mathrm{C}$. The metal dispersion was calculated from the volume of consumed $\mathrm{O}_{2}$ following the equation: $\mathrm{M}_{\mathrm{S}} \mathrm{H}+3 / 4 \mathrm{O}_{2} \rightarrow \mathrm{M}_{\mathrm{S}} \mathrm{O}+1 / 2 \mathrm{H}_{2} \mathrm{O}, \mathrm{M}_{\mathrm{S}}$ being the surface, i.e. accessible metallic atoms. Palladium dispersion was evaluated from Transmission Electron Microscopy (TEM) images obtained with a Tecnai - JEM 2100F. The $\mathrm{H}_{2}-\mathrm{O}_{2}$ method is not reliable for Pd and TEM analysis was used to estimate the dispersion.

\subsection{Hydrothermal stability test}

The metallic catalyst was first reduced at $450^{\circ} \mathrm{C}$ under hydrogen flow $\left(4 \mathrm{~L}^{-\mathrm{h}^{-1}} \cdot \mathrm{g}_{\mathrm{cat}}{ }^{-1}\right)$ during $2 \mathrm{~h}$ and then loaded in a $500 \mathrm{~mL}$ autoclave. The autoclave was filled with $250 \mathrm{~mL}$ of degassed water and put under nitrogen atmosphere. It was then heated to $225^{\circ} \mathrm{C}$, while stirring at $800 \mathrm{rpm}$. The autogenous pressure was 25 bar. Water was predominantly liquid under these conditions. After $2 \mathrm{~h}$, the autoclave was cooled to room temperature. The catalyst was further dried overnight at $110^{\circ} \mathrm{C}$ and characterized.

\subsection{Catalytic test of sorbitol transformation}

The sorbitol transformation reaction was carried out in a fixed-bed reactor already described [22]. Prior to reaction, the fresh catalyst was reduced under hydrogen flow $\left(3 \mathrm{~L} \cdot \mathrm{h}^{-1} \cdot \mathrm{g}_{\mathrm{cat}}{ }^{-1}\right)$ at $450^{\circ} \mathrm{C}$ for $2 \mathrm{~h}$. The 10 wt.\% aqueous sorbitol solution was introduced with hydrogen co-feeding. The hydrogen/sorbitol molar ratio was 25 . Four sets of operating conditions were successively applied: 1) $200^{\circ} \mathrm{C}, 22 \mathrm{bar}, \mathrm{WHSV}=2 \mathrm{~h}^{-1}$; 2) $220^{\circ} \mathrm{C}, 29 \mathrm{bar}, \mathrm{WHSV}=2 \mathrm{~h}^{-1}$; 3) $240^{\circ} \mathrm{C}, 37 \mathrm{bar}, \mathrm{WHSV}=2 \mathrm{~h}^{-1}$; 4) $240^{\circ} \mathrm{C}, 37 \mathrm{bar}, \mathrm{WHSV}=4 \mathrm{~h}^{-1}$. The weight hourly space velocity (WHSV) was based on the diluted solution of sorbitol: WHSV = (mass flow rate of feed solution)/(mass of catalyst). For each set of operating conditions, several samples were taken during 8 to $16 \mathrm{~h}$. Catalytic conversions and products selectivity were stable during this time.

At the end of the test, the spent catalyst was rinsed with degassed water during $3 \mathrm{~h}$ at $240^{\circ} \mathrm{C}, 36 \mathrm{bar}$ 
under nitrogen flow, and stripped with nitrogen under the same conditions. It was then dried overnight at $110^{\circ} \mathrm{C}$, then unloaded and separated from $\mathrm{SiC}$ by sieving. Before nitrogen adsorption-desorption characterization, the spent catalyst was progressively calcined at $500^{\circ} \mathrm{C}$ under diluted air with an exothermicity control.

\subsection{Products analysis}

The average time-on-stream was $90 \mathrm{~h}$. The analytical methods and methods of calculating the carbon balance, the sorbitol conversion and the yields of products were described previously [22]. $\mathrm{CO}_{2}$ in the gaseous effluent was analyzed by gas chromatography using a Varian Porapak-Q capillary column, helium as carrier gas and a Thermal Conductivity Detector (TCD). Gaseous hydrocarbons were analyzed by gas chromatography using an Agilent PONA column, helium as carrier gas and a flame ionization detector (FID). All the detected compounds in gas phase were identified and quantified. Sorbitol and poly-oxygenated compounds (polyols, anhydrosorbitol, isosorbide) were analyzed by HPLC using a Waters 2414 refractive index detector (RID) and a Phenomenex Rezex

RCM-Ca ${ }^{2+}$ column with ultrapure water as the mobile phase. Light aqueous compounds (alcohols, ketones) were analyzed by gas chromatography using a flame ionization detector (FID) and an Agilent PONA column. Carboxylic acids were analyzed by ionic chromatography using a Dionex AS18 column and a conductimeter detector. Total carbon content in the aqueous phase was measured by TOC analysis in an external laboratory (SGS Rouen).

The total carbon balance is based on the carbon in the aqueous phase measured by TOC, the gaseous hydrocarbons analyzed by GC-FID and the $\mathrm{CO}_{2}$ analyzed by GC-TCD. It can be expressed as follows:

$$
C \text { balance }=\frac{\sum\left(\text { carbon } \%_{i} \times C_{i} \times Q_{\text {gas }} \times M_{i}\right)+\mathbf{C}_{\text {Toc }} \times \mathbf{Q}_{\text {effluent }}}{{\text { carbon } \%_{\text {sorbitol }}} \times \mathbf{C}_{\text {feed }} \times \mathbf{Q}_{\text {feed }}} \times 100
$$

with $\mathrm{C}_{\mathrm{i}}$ : $\mathrm{i}$ compound concentration in the gas phase (mol\%); $\mathrm{C}_{\mathrm{TOC}}$ : carbon concentration in aqueous phase given by TOC ( $\mathrm{g}_{\text {carbon }} \cdot \mathrm{g}^{-1}$ ); $\mathrm{Q}_{\text {effluent }}$ : liquid flow after the separator, assumed to be equal to $\mathrm{Q}_{\text {feed }}$ 
regulator $\left(\mathrm{mol}_{\mathrm{min}}{ }^{-1}\right)$; $\mathrm{Q}_{\text {feed }}$ : feed flow before the reactor $\left(\mathrm{g} \cdot \mathrm{min}^{-1}\right)$; carbon $\%_{\mathrm{i}}$ : see below; $\mathrm{M}_{\mathrm{i}}$ : i molar weight $\left(\mathrm{g} \cdot \mathrm{mol}^{-1}\right)$.

$$
\text { carbon } \%_{i}=\frac{C \text { atom number in } i \times M_{C}}{M_{i}} \times 100
$$

with $\mathrm{M}_{\mathrm{C}}$ : carbon atomic weight $\left(12.01 \mathrm{~g} \cdot \mathrm{mol}^{-1}\right) ; \mathrm{M}_{\mathrm{i}}$ : i molar weight (g.mol ${ }^{-1}$ ).

The products results are presented as carbon distribution, i.e. the ratio between the molar yield of a given compound (e.g. $\mathrm{CO}_{2}$ ) or group of compounds (e.g. hydrocarbons) and the sum of all the analyzed products, including sorbitol. The carbon distribution in a group of compounds (e.g. hydrocarbons) as a function of carbon atom numbers is calculated as follows:

$$
D_{n}=\frac{\sum Y(\text { hydrocarbons with } n \text { carbon atoms })}{Y(\text { hydrocarbons })} \times 100
$$

with $\mathrm{D}_{\mathrm{n}}$ : carbon distribution of compounds with $\mathrm{n}$ carbon atoms; $\mathrm{Y}$ : carbon molar yield.

\section{Results and discussion}

\subsection{Catalysts characterizations}

Table 1 presents the physical and chemical properties of the support and the metallic catalysts. The monoclinic zirconia support is a mesoporous material with a specific surface area around $75 \mathrm{~m}^{2} \cdot \mathrm{g}^{-1}$ and an average pore diameter around $8.5 \mathrm{~nm}$. The metal impregnation does not have any impact on the support textural properties (Supporting Information, Figure S1 and S2) The XRD analyses (Supporting Information, Figure S3) show that monoclinic zirconia is the major phase, but a minor tetragonal phase is also present. The crystalline properties remain the same after metal impregnation. The properties of the acid catalyst $\mathrm{TiO}_{2}-\mathrm{WO}_{\mathrm{x}}$ are reminded in Table 1: it is a mesoporous rutile support, on which a tungsten phase is deposited $(\mathrm{W}$ content $=13.4 \mathrm{wt} . \%)$.

Metal particle size and shape play a major role in catalysis [37]. The metal dispersion was measured by $\mathrm{H}_{2}-\mathrm{O}_{2}$ titration for platinum- and iridium-based catalysts and by TEM observations for palladiumbased sample. Platinum catalyst is well dispersed (63\%, corresponding to an average particle size of $1.8 \mathrm{~nm}$ when considering a truncated cuboctahedral shape), whereas the iridium dispersion value is 
$41 \%$ corresponding to an average particle size of $3.2 \mathrm{~nm}$. The palladium particle size observed by TEM ranges from 0.5 to $2 \mathrm{~nm}$ (Figure 1), indicating a dispersion of at least 60\%.

\subsection{Stability of the catalysts in aqueous medium}

\subsubsection{In a neutral medium}

The metallic catalysts were submitted to the hydrothermal stability test (ST: $225^{\circ} \mathrm{C}, 2 \mathrm{~h}$, in liquid water). The hydrothermal stability test was designed to study the effect of water on the physical and chemical properties of the catalyst. We showed in a previous study that the applied operating conditions $\left(2 \mathrm{~h}, 225^{\circ} \mathrm{C}\right.$, autogenous pressure $)$ are sufficient to observe water-induced modifications [21]. The results of post-test characterizations are summarized in Table 2.

The textural and crystalline properties of the zirconia support are not modified by the hydrothermal medium. The monoclinic phase still prevails, with a minor tetragonal phase (Figure 2). No drastic change of Pt and Ir contents are measured after test, indicating the absence of leaching in solution. In the case of palladium a decrease of $0.3 \mathrm{wt} . \%$ in metal content is observed.

The platinum dispersion decreases from 63 to $53 \%$ after hydrothermal stability test, corresponding

to an average diameter increase from $1.8 \mathrm{~nm}$ to $2.0 \mathrm{~nm}$. This value is not considered as significant, given the analytical error. However some modifications of the metal particle shape could be expected [38]. On the XRD diffractogram, a shoulder corresponding to $\mathrm{Pt}^{\circ}$ is observed. In the case of iridium, the observed particle sintering (dispersion loss from $41 \%$ to $19 \%$ ) is not clearly detected by XRD analysis (Figure 2). For palladium, no particle larger than $2 \mathrm{~nm}$ was observed by TEM; however the number of observed particles is too low to give a reliable average size.

The behaviour of zirconia supported catalysts in aqueous medium contrasts with that of silicaalumina supported platinum catalyst described in a previous study [21]: platinum particles sinter quickly and heterogeneously when supported on silica-alumina, whereas they are more stable when supported on zirconia. The self stability of the support could be responsible for that better metallic phase stability. However, the stability depends on the nature of the metallic phase, as iridium sinters significantly on the same zirconia support. The metal-support interaction is thus crucial for metal particles stability. 
Besides, the acid catalyst $\mathrm{TiO}_{2}-\mathrm{WO}_{\mathrm{x}}$ also demonstrated a good hydrothermal stability: its porosity is not modified by the hydrothermal medium, as well as the crystalline phase (Table 2). No tungsten leaching was observed.

\subsubsection{In the reaction medium}

The metallic catalysts were then mixed with tungstated titania oxide for the sorbitol transformation test (TSorb). The separation of both components after test being impossible, the characterizations of used catalysts were thus performed on the overall mixture. Table 3 summarizes the results obtained on spent metallic supported catalysts.

The textural properties of the zirconia support and of the tungstated titania are not modified by the

reaction medium (regarding the precision of the calculation). The shape of the desorption branch of nitrogen adsorption-desorption isotherms reveals that the mechanical mixtures present bimodal pore size distributions as a result of the superposition of the distributions obtained on the zirconia support and on the tungstated titania oxide (Figure 3).

The metal contents do not change significantly during the catalytic test. Only a slight decrease in palladium content is observed. Palladium leaching is thus possible. However a sintering of the platinum particles occurs in the reaction medium whereas the catalyst seemed to be stable in a neutral hydrothermal medium (Table 2, ST samples). The acidity of the reaction medium, the presence of chelating oxygenated species and/or the exposure time are certainly responsible for this sintering effect. The sintering of the zirconia supported platinum particles is however less important than the one observed in a previous work with silica-alumina support [21]. The iridium sintering is similar in a neutral medium (ST) and in the reaction medium (TSorb), indicating that water is the major sintering agent in this case. Finally, the palladium dispersion after test was not evaluated by TEM, due to a poor Pd-Zr contrast which makes the observation of Pd particles difficult.

\subsection{Catalytic performances in sorbitol transformation}

The metallic catalysts were tested in mechanical mixture with the tungstated titania, previously identified as the optimal acidic catalyst for sorbitol transformation [23]. Figure 4 shows the global carbon distribution for each mechanical mixture, at different temperatures and spatial velocities. 
At $200^{\circ} \mathrm{C}$, the sorbitol conversion is between $85 \%$ (Pt) and $65 \%$ (Ir). The two first steps of sorbitol transformation, i.e. successive dehydrations towards 1,4-anhydrosorbitol and isosorbide, are purely acidic-catalyzed reactions. The metallic sites are mainly involved in the mechanism from the third step, i.e. isosorbide transformation. The ratio (sorbitol + anhydrosorbitol + isosorbide)/(total carbon) can then be considered as an indicator of the bifunctional activity of the catalytic system. The metallic catalysts are then ordered by decreasing activity as follows:

$$
\begin{gathered}
\text { Pt }>\text { Pd }>\text { Ir at } 200^{\circ} \mathrm{C} \\
\text { Pt }>>\text { Ir }>\text { Pd from } 220^{\circ} \mathrm{C} \text { to } 240^{\circ} \mathrm{C} .
\end{gathered}
$$

Platinum is the most active metal, much more active than palladium and iridium when the temperature reaches $220^{\circ} \mathrm{C}$. The $\mathrm{Pd} / \mathrm{ZrO}_{2}$ and $\mathrm{Ir} / \mathrm{ZrO}_{2}$ catalysts (mixed with $\mathrm{TiO}_{2}-\mathrm{WO}_{\mathrm{x}}$ ) lead mainly to anhydrosorbitol and isosorbide, showing that in these systems the metallic sites are little active. The undesired reactions of $\mathrm{C}-\mathrm{C}$ cleavage leading to $\mathrm{CO}_{2}$ production are limited. Nevertheless, an important CO production was observed over a $\mathrm{Pd} / \mathrm{ZrO}{ }_{2}+\mathrm{TiO}_{2}-\mathrm{WO}_{\mathrm{x}}$ mechanical mixture containing three times more palladium than the one presented in this article. This result indicates that some CO production is highly likely in the presence of palladium and suspected in the case of iridium.

At $240^{\circ} \mathrm{C}$ and a WHSV of $2 \mathrm{~h}^{-1}$, the "sorbitol + anhydrosorbitol + isosorbide" global conversion reaches only $16 \%_{\text {carbon }}$ in the case of palladium and $53 \%_{\text {carbon }}$ in the case of iridium whereas it is complete in the case of platinum. However, palladium- and iridium-based catalysts lead to low yields of hydrocarbons (around $1.5 \%_{\text {carbon }}$ ) and of identified mono-oxygenated compounds other than anhydrosorbitol and isosorbide (around $15 \%_{\text {carbon }}$ ).

The hydrocarbons and mono-alcohols yields were high enough to allow an estimation of the carbon distribution inside both families only at $240^{\circ} \mathrm{C}, 2 \mathrm{~h}^{-1}$ (Figure 5). The obtained distributions in the presence of platinum are represented too, but the comparison between the three metals has to be considered cautiously given the difference in global conversion. Palladium leads predominantly to C5C6 hydrocarbons. Iridium favours n-pentane formation, showing a mono-cleavage behaviour already reported for this metal [39]. Platinum leads to a well distributed selectivity to C4-C5-C6 hydrocarbons. Regarding the alcohols, palladium and iridium both lead to a high part of pentanols.

Concerning the carbon distributions within the oxygenated compounds at $240^{\circ} \mathrm{C}, 2 \mathrm{~h}^{-1}$, apart from 
anhydrosorbitol and isosorbide, the major oxygenated compounds are pentanols in the case of iridium, attesting a high selectivity for C5 compounds, and unsaturated compounds such as ketones and heterocycles in the case of palladium, revealing a limiting hydrogenation step. Moreover, in the case of iridium the identification ratio is only $64 \%$ (for detailed data, see Table S5 in Supporting Information).

Palladium- and iridium-based catalysts are poorly active when compared to platinum, whatever the operating conditions. In the case of palladium-based sample, its acidic phase activity predominates over the metallic one, leading to anhydrosorbitol and isosorbide. However, the selectivity in C5-C6 compounds within hydrocarbons is high for both palladium- and iridium-based catalysts. This indicates that $\mathrm{C}-\mathrm{C}$ cleavage reactions such as decarbonylation and decarboxylation are less favoured in the presence of palladium and iridium than in the presence of platinum. The low identification ratio obtained with iridium, along with the particular selectivity for C5 compounds, shows that the reaction pathway depends on the metal used in the catalytic system and may be particularly different in the presence of iridium.

\subsection{Influence of acid/metal balance on the catalytic performances}

To evaluate the impact of the metal/acid ratio on the catalytic performances, three mechanical mixtures with three different ratios of the most active metallic catalyst, $2.2 \% \mathrm{Pt} / \mathrm{ZrO}_{2}$, with $\mathrm{TiO}_{2}-\mathrm{WO}_{\mathrm{x}}$ were tested. The acidic phase was also tested alone to understand the role of tungstated titania on the sorbitol transformation reaction.

The mechanical mixtures were prepared by varying the amount of $\mathrm{Pt} / \mathrm{ZrO}_{2}$ while keeping constant the amount of $\mathrm{TiO}_{2}-\mathrm{WO}_{\mathrm{x}}$. Table 4 summarizes the mass ratios of the mechanical mixtures, the platinum global content and the platinum content regarding the mass of acidic catalyst. Figure 6 depicts the global carbon distribution in the sorbitol transformation effluent over the four different catalytic systems.

In absence of metallic catalyst, the tungstated titania gives mainly oxygenated products with isosorbide as the major one with $86 \%$ yield at $240^{\circ} \mathrm{C}$. As expected, the acidic phase catalyses mainly dehydration reactions. When the amount of $\mathrm{Pt} / \mathrm{ZrO}_{2}$ increases, the hydrocarbons yield increases, 
indicating a higher reaction extent. The $\mathrm{CO}_{2}$ yield increases too, meaning that the $\mathrm{C}-\mathrm{C}$ cleavage reactions are favoured. Moreover, the part of $\mathrm{CO}_{2}$ and hydrocarbons increases with temperature increase or spatial velocity decrease, whatever the mechanical mixture. At $240^{\circ} \mathrm{C}, 2 \mathrm{~h}^{-1}$, the hydrocarbon yield reaches maximum values for $\mathrm{Pt} / \mathrm{ZrO}_{2}: \mathrm{TiO}_{2}-\mathrm{WO}_{\mathrm{x}}$ (20:80) and (33:67): 39\% $\%_{\text {carbon }}$ and $44 \%_{\text {carbon, }}$, respectively. It is well known that C-C hydrogenolysis reactions have an activation energy barrier higher than hydrogenation reactions. Thus, the temperature increase favours C-C cleavage reactions leading to an increased $\mathrm{CO}_{2}$ yield.

The acid/metal balance has also a strong impact on the carbon distribution within hydrocarbons (Figure 7). The selectivity in C6 compounds decreases when the platinum content increases. In the case of the highest platinum content (0.73 wt.\% for $\mathrm{Pt} / \mathrm{ZrO}_{2}: \mathrm{TiO}_{2}-\mathrm{WO}_{\mathrm{x}}$ (33:67)), the selectivity in C6 compounds decreases when the temperature increases. The carbon distribution within the alcohol fraction (Figure 8) shows that for the 11:89 and 20:80 mechanical mixtures, the catalytic system produces mainly pentanols and hexanols, indicating a high selectivity for $\mathrm{C}-\mathrm{O}$ cleavage reactions whatever the operating conditions. When the $\mathrm{Pt} / \mathrm{ZrO}_{2}$ part in the mechanical mixture reaches $33 \%$, the C6 compounds are not the major alcohols anymore at $240^{\circ} \mathrm{C}, 2 \mathrm{~h}^{-1}$, evidencing that C-C cleavage reactions occur.

Table 5 presents the detailed carbon distribution in the oxygenated compounds. The composition of the aqueous phase changes with the platinum content of the catalytic system: the higher the platinum content, the higher the mono-oxygenated compounds proportion. Most of the carbon in polyoxygenated compounds is present as 1,4-anhydrosorbitol or isosorbide. The reaction step polyoxygenated compounds $\rightarrow$ mono-oxygenated compounds can be simplified as isosorbide $\rightarrow$ monooxygenated compounds. Isosorbide requires a ring-opening dehydration/hydrogenation reaction to be further transformed [19]. This step is catalysed by the metal active sites. Thus in metal limiting conditions, the higher Pt loading leads to a higher transformation of poly-oxygenated compounds into mono-oxygenated compounds.

The unsaturated compounds such as ketones, furanic and pyranic derivatives are major compounds, evidencing a lack of hydrogenation sites. The hexanones, 2,5-dimethyltetrahydrofuran and 2methyltetrahydropyran represent a "hydrocarbon tank": if more hydrogenation sites were available, 
these compounds would be transformed into hexane. For example, in the case of the $\mathrm{Pt} / \mathrm{ZrO}{ }_{2}: \mathrm{TiO}_{2}$ $\mathrm{WO}_{\mathrm{x}}(20: 80)$ system, at $240^{\circ} \mathrm{C}, 2 \mathrm{~h}^{-1}$, the C6 unsaturated compounds yield is $12 \%_{\text {carbon }}$ which could theoretically be transformed in hexane.

The modification of the metal/acid balance modifies selectivity. The optimal mass ratio is 20:80, with a compromise between a high C6 hydrocarbons selectivity and a high activity. This system is however limited by a lack of hydrogenation of ketones and heterocycles.

\section{Conclusions}

This work was devoted to the study of bifunctional catalytic systems for sorbitol transformation in order to maximize the C6 hydrocarbons yield. First, we evaluated different metallic catalysts composed of a Pt, Pd or Ir phase dispersed on the same zirconia support and mixed mechanically with the same acidic phase $\left(\mathrm{TiO}_{2}-\mathrm{WO}_{\mathrm{x}}\right)$. The influence of the metal/acid phases ratio was studied in a second step by varying the composition of the mechanical mixtures.

The metallic catalysts $\left(\mathrm{M} / \mathrm{ZrO}_{2}, \mathrm{M}=\mathrm{Pt}\right.$, Pd or Ir) are more stable in hydrothermal media than the $\mathrm{Pt} / \mathrm{SiO}_{2}-\mathrm{Al}_{2} \mathrm{O}_{3}$ reference catalyst: slight metal leaching is observed for Pd supported catalyst, the sintering of metal particles is limited in a neutral medium and the support structure and texture are not modified by the hot water environment. Using a stable support $\left(\mathrm{ZrO}_{2}\right)$ to stabilize the metallic phase is thus an efficient method.

Regarding the catalytic performances during sorbitol transformation, palladium- and iridium-based catalysts are poorly active when compared to platinum. This low activity is consistent with the literature on polyols transformation [30, 40, 41]. Palladium and iridium systems lead to interesting selectivity into C5-C6 compounds, indicating that C-C cleavage reaction are disfavoured. However their yields are too low for further application as monometallic catalysts. A combination with an active metal in bimetallic system could b interesting for increasing selectivity to long hydrocarbons.

The platinum-based catalyst activity can be tuned by varying the content of $\mathrm{Pt} / \mathrm{ZrO}_{2}$ in the mechanical mixture with $\mathrm{TiO}_{2}-\mathrm{WO}_{\mathrm{x}}$. The modification of the metal/acid balance modifies selectivity. The 20:80 mass ratio is a compromise between high C6 hydrocarbons selectivity and high activity. Even for Pt, hydrocarbon production is limited by the hydrogenation of ketones and heterocycles. 
The research of a metallic phase being active and selective for hydrogenation reactions against C-C cleavage reactions is still a challenge for sorbitol transformation. The modification of active phases such as platinum by promoters blocking the catalytic sites responsible for C-C cleavage reactions may be a way of improvement.

5

[1] E. Thomas, Science, 285 (1999) 1209.

[2] S. Murat Sen, C.A. Henao, D.J. Braden, J.A. Dumesic and C.T. Maravelias, Chem. Eng. Sci., 67 (2012) 57.

[3] D.A. Simonetti and J.A. Dumesic, ChemSusChem, 1 (2008) 725.

15 [4] G.W. Huber, J.N. Chheda, C.J. Barrett and J.A. Dumesic, Science, 308 (2005) 1446.

[5] G.W. Huber, R.D. Cortright and J.A. Dumesic, Angew. Chem. Int. Ed., 43 (2004) 1549.

[6] G.W. Huber and J.A. Dumesic, Catal. Today, 111 (2006) 119.

[7] L. Vilcocq, A. Cabiac, C. Especel, E. Guillon and D. Duprez, Oil Gas Sci. Technol., 68 (2013), 841.

20 [8] B. Kusserow, S. Schimpf and P. Claus, Adv. Synth. Catal., 345 (2003) 289.

[9] P. Gallezot, N. Nicolaus, G. Flèche, P. Fuertes and A. Perrard, J. Catal., 180 (1998) 51.

[10] A. Shrotri, A. Tanksale, J.N. Beltramini, H. Gurav and S.V. Chilukuri, Catal. Sci. Technol., 2 (2012) 1852.

[11] D. Weiping, T. Xuesong, F. Wenhao, Z. Qinghong and W. Ye, Catal. Lett., 133 (2009) 167.

[12] W. Deng, X. Tan, W. Fang, Q. Zhang, Y. Wang, ChemSusChem, 3 (2010) 818.

[13] T. Werty and G.R. Petersen, Topvalue added chemicals from biomass (top 12), in DOE (Editor), 2004.

[14] J.J. Bozell and G.R. Petersen, Green Chem., 12 (2010) 539.

[15] R.M. West, M.H. Tucker, D.J. Braden and J.A. Dumesic, Catal. Commun., 10 (2009) 1743.

30 [16] N. Li, G.A. Tompsett and G.W. Huber, ChemSusChem, 3 (2010) 1154.

[17] Q. Zhang, K. Qiu, B. Li, T. Jiang, X. Zhang, L. Ma and T. Wang, Fuel, 90 (2011) 3468.

[18] J. ten Dam and U. Hanefeld, ChemSusChem, 4 (2011) 1017.

[19] N. Li and G.W. Huber, J. Catal., 207 (2010) 48.

[20] A.V. Kirilin, A.V. Tokarev, E.V. Murzina, L.M. Kustov, J.-P. Mikkola and D.Y. Murzin, 35 ChemSusChem, 3 (2010) 708.

[21] L. Vilcocq, A. Cabiac, C. Especel, S. Lacombe and D. Duprez, Catal. Commun., 15 (2011) 18.

[22] L. Vilcocq, A. Cabiac, C. Especel, S. Lacombe and D. Duprez, Catal. Today, 189 (2012) 117.

[23] L. Vilcocq, R. Koerin, A. Cabiac, C. Especel, S. Lacombe and D. Duprez, Appl. Catal. B, 148149 (2014) 499.

40 [24] A. Wawrzetz, B. Peng, A. Hrabar, A. Jentys, A.A. Lemonidou and J.A. Lercher, J. Catal., 269 (2010) 411.

[25] J.W. Shabaker, G.W. Huber and J.A. Dumesic, J. Catal., 222 (2004) 180.

[26] R.M. Ravenelle, F. Schuber, A. D'Amico, N. Danilina, J.A. van Bokhoven, J.A. Lercher, C.W. Jones and C. Sievers, J. Phys. Chem. C, 114 (2010) 19582. 
[27] R.M. Ravenelle, J.R. Copeland, W.-G. Kim, J.C. Crittenden and C. Sievers, ACS Catal., 1 (2011) 552.

[28] R. Ravenelle, J. Copeland, A. Van Pelt, J. Crittenden and C. Sievers, Top. Catal., 55 (2012)

162.

5 [29] A.L. Jongerius, J.R. Copeland, G.S. Foo, J.P. Hofmann, P.C.A. Bruijnincx, C. Sievers and B.M. Weckhuysen, ACS Catal., 3 (2013) 464.

[30] C. Montassier, D. Giraud, J. Barbier and J.P. Boitiaux, Bull. Soc. Chim. Fr., 2 (1989) 148.

[31] D.K. Sohounloue, C. Montassier and J. Barbier, React. Kinet. Catal. Lett., 22 (1983) 391.

10

[32] L. Gong, Y. Lu, Y. Ding, R. Lin, J. Li, W. Dong, T. Wang and W. Chen, Appl. Catal. A, 390 (2010) 119.

[33] R.R. Soares, D.A. Simonetti and J.A. Dumesic, Angew. Chem. Int. Ed., 45 (2006) 3982.

[34] G.A. Somorjai, Introduction to Surface Chemistry and Catalysis, Wiley, New York, 1994.

[35] J. Lee, Y. Xu and G.W. Huber, Appl. Catal. B, 140-141 (2013) 98.

[36] A. Pottier, C. Chaneac, E. Tronc, L. Mazerolles and J.-P. Jolivet, J. Mater. Chem., 11 (2001)

1116.

[37] A.S. Barnard and L.Y. Chang, ACS Catal., 1 (2011) 76.

[38] S. Cheong, J. Watt, B. Ingham, M.F. Toney and R.D. Tilley, J. Am. Chem. Soc., 131 (2009) 14590.

[39] D.W. Goodman, Catal. Today, 12 (1992) 189.

20 [40] Y. Amada, Y. Shinmi, S. Koso, T. Kubota, Y. Nakagawa and K. Tomishige, Appl. Catal. B, 105 (2011) 117.

[41] R.R. Davda, J.W. Shabaker, G.W. Huber, R.D. Cortright and J.A. Dumesic, Appl. Catal. B, 43 (2003) 13. 


\section{List of Tables}

Table 1. Physical and chemical properties of fresh metallic supported catalysts and of the acid phase $\mathrm{TiO}_{2}-\mathrm{WO}_{\mathrm{x}}$

5 Table 2. Physical and chemical properties of supported metallic catalysts after hydrothermal stability test (ST) $\left(225^{\circ} \mathrm{C}, 2 \mathrm{~h}\right.$, liquid water). The stability of the acid phase $\mathrm{TiO}_{2}-\mathrm{WO}_{\mathrm{x}}$ is presented too.

Table 3. Physical and chemical properties of supported metallic catalysts before and after sorbitol transformation test (TSorb) in mechanical mixing with $\mathrm{TiO}_{2}-\mathrm{WO}_{\mathrm{x}}$.

Table 4. Carbon distribution within oxygenated compounds in the sorbitol transformation effluent. Operating conditions: $240^{\circ} \mathrm{C}, \mathrm{WHSV}=2 \mathrm{~h}^{-1}, \mathrm{M} / \mathrm{ZrO}_{2}+\mathrm{TiO}_{2}-\mathrm{WO}_{x}$ catalyst $(\mathrm{M}=\mathrm{Pt}$, Pd or Ir).

Table 5. Compositions of the $\mathrm{Pt} / \mathrm{ZrO}_{2}+\mathrm{TiO}_{2}-\mathrm{WO}_{\mathrm{x}}$ mechanical mixtures.

Table 6. Carbon distribution within oxygenated compounds in the sorbitol transformation effluent. Operating conditions: $240^{\circ} \mathrm{C}$, WHSV $=4 \mathrm{~h}^{-1}, \mathrm{Pt} / \mathrm{ZrO}_{2}+\mathrm{TiO}_{2}-\mathrm{WO}_{\mathrm{x}}$ catalyst with four different mass ratios. 


\section{Figures captions}

Figure 1. Sorbitol transformation: general scheme (WGS: water gas shift reaction). Adapted from ref. 22.

5 Figure 2. TEM pictures of $\mathrm{Pd} / \mathrm{ZrO}_{2}$ catalyst.

Figure 3. $\mathrm{XRD}$ patterns of $\mathrm{Pt} / \mathrm{ZrO}_{2}, \mathrm{Pd} / \mathrm{ZrO}_{2}$ and $\mathrm{Ir} / \mathrm{ZrO}_{2}$ catalysts after hydrothermal stability test (ST) $\left(225^{\circ} \mathrm{C}, 2 \mathrm{~h}\right.$, liquid water). M: monoclinic zirconia; T: tetragonal zirconia.

Figure 4. Pore size distribution of monoclinic zirconia (fresh), $\mathrm{TiO}_{2}-\mathrm{WO}_{\mathrm{x}}$ (fresh), $\mathrm{Pt} / \mathrm{ZrO}_{2}, \mathrm{Pd} / \mathrm{ZrO}_{2}$ and $\mathrm{Ir} / \mathrm{ZrO}{ }_{2}$ catalysts in mechanical mixture with $\mathrm{TiO}_{2}-\mathrm{WO}_{\mathrm{x}}$ after sorbitol transformation test (spent catalysts). Values calculated with the BJH method, on the desorption isotherm.

Figure 5. Carbon distribution in the global effluent of sorbitol transformation over mechanical mixtures $\mathrm{Pt} / \mathrm{ZrO}_{2}+\mathrm{TiO}_{2}-\mathrm{WO}_{\mathrm{x}}(\mathrm{Pt}) ; \mathrm{Pd} / \mathrm{ZrO}_{2}+\mathrm{TiO}_{2}-\mathrm{WO}_{\mathrm{x}}(\mathrm{Pd}) ; \mathrm{Ir} / \mathrm{ZrO}_{2}+\mathrm{TiO}_{2}-\mathrm{WO}_{\mathrm{x}}$ (Ir).Hydrocarbons are n-alkanes in majority, cyclopentane, cyclohexane and methylcyclopentane in minority. Alkenes were detected as traces. The composition of the oxygenated compounds is detailed in Table 4.

Figure 6. Carbon distribution in the hydrocarbons (a) and in the alcohols (b) during sorbitol transformation over mechanical mixtures $\mathrm{Pt} / \mathrm{ZrO}_{2}+\mathrm{TiO}_{2}-\mathrm{WO}_{\mathrm{x}}(\mathrm{Pt})$; $\mathrm{Pd} / \mathrm{ZrO}_{2}+\mathrm{TiO}_{2}-\mathrm{WO}_{\mathrm{x}}(\mathrm{Pd})$; $\mathrm{Ir} / \mathrm{ZrO}_{2}+\mathrm{TiO}_{2}-\mathrm{WO}_{\mathrm{x}}$ (Ir) at $240^{\circ} \mathrm{C}, \mathrm{WHSV}=2 \mathrm{~h}^{-1}$. Hydrocarbons are n-alkanes in majority, cyclopentane, cyclohexane and methylcyclopentane in minority.

Figure 7. Carbon distribution in the global effluent of sorbitol transformation over mechanical mixtures $\mathrm{Pt} / \mathrm{ZrO}_{2}+\mathrm{TiO}_{2}-\mathrm{WO}_{\mathrm{x}}$ with different global platinum contents.

Figure 8. Carbon distribution in the hydrocarbons during sorbitol transformation over mechanical mixtures $\mathrm{Pt} / \mathrm{ZrO}_{2}+\mathrm{TiO}_{2}-\mathrm{WO}_{\mathrm{x}}$ with different global platinum contents: 0.24 wt.\% (•); 0.44 wt.\% (•); 0.73 wt.\% ( $\mathbf{\Delta}$ ) at various operating conditions: (a) $220^{\circ} \mathrm{C}, 2 \mathrm{~h}^{-1}$; (b) $240^{\circ} \mathrm{C}, 4 \mathrm{~h}^{-1}$. 
Figure 9. Carbon distribution in the alcohols during sorbitol transformation over mechanical mixtures $\mathrm{Pt} / \mathrm{ZrO}_{2}+\mathrm{TiO}_{2}-\mathrm{WO}_{\mathrm{x}}$ with different global platinum contents: 0.24 wt.\% (•); 0.44 wt.\% (•); 0.73 wt. \% ( $\Delta$ ) at various operating conditions: (a) $220^{\circ} \mathrm{C}, 2 \mathrm{~h}^{-1}$; (b) $240^{\circ} \mathrm{C}, 4 \mathrm{~h}^{-1}$. 


\section{Tables}

Table 1. Physical and chemical properties of fresh metallic supported catalysts and of the acid phase $\mathrm{TiO}_{2}-\mathrm{WO}_{\mathrm{x}}$.

\begin{tabular}{|c|c|c|c|c|c|}
\hline Catalyst & $\mathrm{ZrO}_{2}$ & $\mathrm{Pt} / \mathrm{ZrO}_{2}$ & $\mathrm{Pd} / \mathrm{ZrO}_{2}$ & $\mathrm{Ir} / \mathrm{ZrO}_{2}$ & $\mathrm{TiO}_{2}-\mathrm{WO}_{\mathrm{x}}$ \\
\hline Metal content (wt.\%) & - & 2.1 & 1.2 & 1.9 & - \\
\hline Cl content (wt.\%) & - & 1.2 & - & 1.0 & - \\
\hline Dispersion $(\%)^{\mathrm{a}}$ & - & 63 & - & 41 & - \\
\hline $\begin{array}{l}\text { Average particle diameter } \\
(\mathrm{nm})^{\mathrm{b}}\end{array}$ & - & 1.8 & - & 3.2 & - \\
\hline Main crystalline phases ${ }^{c}$ & $\begin{array}{c}\mathrm{ZrO}_{2} \\
\text { monoclin. }\end{array}$ & $\begin{array}{c}\mathrm{ZrO}_{2} \\
\text { monoclin. }\end{array}$ & $\begin{array}{c}\mathrm{ZrO}_{2} \\
\text { monoclin. }\end{array}$ & $\mathrm{ZrO}_{2}$ & $\mathrm{TiO}_{2}$ rutile \\
\hline BET surface area $\left(\mathrm{m}^{2} \cdot \mathrm{g}^{-1}\right)$ & 79 & 74 & 68 & 72 & 125 \\
\hline Porous volume $\left(\mathrm{mL} \cdot \mathrm{g}^{-1}\right)$ & 0.22 & 0.21 & 0.21 & 0.20 & 0.37 \\
\hline Average pore diameter (nm) & 8.3 & 8.6 & 8.8 & 8.9 & 10.4 \\
\hline
\end{tabular}

$5 \overline{{ }^{a} \text { Dispersion calculated from } \mathrm{H}_{2}-\mathrm{O}_{2} \text { titration using the equation } \mathrm{MH}+3 / 4 \mathrm{O}_{2} \rightarrow \mathrm{MO}+1 / 2 \mathrm{H}_{2} \mathrm{O} \text {; }{ }^{b} \text { Calculated }}$ following the cuboctahedral model; ${ }^{\mathrm{c}}$ Determined from XRD. 
Table 2. Physical and chemical properties of supported metallic catalysts and of the acid phase $\mathrm{TiO}_{2}$ $\mathrm{WO}_{\mathrm{x}}$ after hydrothermal stability test (ST) $\left(225^{\circ} \mathrm{C}, 2 \mathrm{~h}\right.$, liquid water).

\begin{tabular}{|c|c|c|c|c|}
\hline Catalyst & $\mathrm{Pt} / \mathrm{ZrO}_{2}-\mathrm{ST}$ & $\mathrm{Pd} / \mathrm{ZrO}_{2}-\mathrm{ST}$ & $\mathrm{Ir} / \mathrm{ZrO}_{2}$-ST & $\mathrm{TiO}_{2}-\mathrm{WO}_{\mathrm{x}}-\mathrm{ST}$ \\
\hline Metal content (wt.\%) & 2.1 & 0.9 & 1.8 & - \\
\hline Dispersion (\%) ${ }^{\mathrm{a}}$ & 53 & - & 19 & - \\
\hline $\begin{array}{l}\text { Average particle diameter } \\
(\mathrm{nm})^{\mathrm{b}}\end{array}$ & 2.0 & - & 6.5 & - \\
\hline Main crystalline phases ${ }^{c}$ & $\begin{array}{c}\mathrm{ZrO}_{2} \text { monoclinic } \\
\mathrm{Pt}^{\circ}\end{array}$ & $\underset{\mathrm{Pd}^{\circ}}{\mathrm{ZrO}_{2}}$ monoclinic & $\underset{\mathrm{Ir}^{\circ}}{\mathrm{ZrO}_{2}} \underset{\text { monoclinic }}{ }$ & $\mathrm{TiO}_{2}$ rutile \\
\hline BET surface area $\left(\mathrm{m}^{2} \cdot \mathrm{g}^{-1}\right)$ & 76 & 81 & 77 & 127 \\
\hline Porous volume (mL.g $\left.{ }^{-1}\right)$ & 0.20 & 0.21 & 0.20 & 0.38 \\
\hline Average pore diameter (nm) & 8.9 & 8.2 & 8.2 & 11.1 \\
\hline
\end{tabular}

$\overline{{ }^{a}}$ Dispersion calculated from $\mathrm{H}_{2}-\mathrm{O}_{2}$ titration using the equation $\mathrm{MH}+3 / 4 \mathrm{O}_{2} \rightarrow \mathrm{MO}+1 / 2 \mathrm{H}_{2} \mathrm{O}$; ${ }^{b}$ Calculated 5 following the cuboctahedral model; ${ }^{\mathrm{c}}$ Determined from XRD. 
Table 3. Physical and chemical properties of supported metallic catalysts before and after sorbitol transformation test (TSorb) in mechanical mixing with $\mathrm{TiO}_{2}-\mathrm{WO}_{\mathrm{x}}$.

\begin{tabular}{|c|c|c|c|c|c|}
\hline Catalyst & $\begin{array}{c}\mathrm{TiO}_{2}-\mathrm{WO}_{\mathrm{x}}+ \\
\mathrm{M} / \mathrm{ZrO}_{2} \text { fresh }\end{array}$ & $\begin{array}{c}\mathrm{TiO}_{2}-\mathrm{WO}_{\mathrm{x}^{-}} \\
\text {TSorb }\end{array}$ & $\begin{array}{c}\mathrm{TiO}_{2}-\mathrm{WO}_{\mathrm{x}}+ \\
\mathrm{Pt} / \mathrm{ZrO}_{2^{-}} \\
\mathrm{TSorb}\end{array}$ & $\begin{array}{c}\mathrm{TiO}_{2}-\mathrm{WO}_{\mathrm{x}}+ \\
\mathrm{Pd} / \mathrm{ZrO}_{2^{-}} \\
\mathrm{TSorb}\end{array}$ & $\begin{array}{c}\mathrm{TiO}_{2}-\mathrm{WO}_{\mathrm{x}}+ \\
\mathrm{Ir} / \mathrm{ZrO}_{2^{-}} \\
\mathrm{TSorb}\end{array}$ \\
\hline Metal (wt.\%) & d & - & 2.1 & 1.0 & 2.0 \\
\hline Dispersion (\%) ${ }^{\mathrm{a}}$ & d & - & 25 & - & 21 \\
\hline $\begin{array}{l}\text { Average particle diameter } \\
(\mathrm{nm})^{\mathrm{b}}\end{array}$ & d & - & 4.5 & - & 6.0 \\
\hline Main crystalline phases ${ }^{c}$ & $\begin{array}{l}\mathrm{ZrO}_{2} \\
\text { monoclinic; }\end{array}$ & - & $\frac{\mathrm{ZrO}_{2}}{\text { monoclinic; }}$ & $\begin{array}{c}\mathrm{ZrO}_{2} \\
\text { monoclinic; }\end{array}$ & $\begin{array}{l}\mathrm{ZrO}_{2} \\
\text { monoclinic; }\end{array}$ \\
\hline & $\mathrm{TiO}_{2}$ rutile & & $\mathrm{TiO}_{2}$ rutile & $\mathrm{TiO}_{2}$ rutile & $\mathrm{TiO}_{2}$ rutile \\
\hline BET surface area $\left(\mathrm{m}^{2} \cdot \mathrm{g}^{-1}\right)$ & 96 & $127^{\mathrm{d}}$ & 92 & 104 & 99 \\
\hline Porous volume $\left(\mathrm{mL} \cdot \mathrm{g}^{-1}\right)$ & 0.31 & $0.35^{\mathrm{d}}$ & 0.31 & 0.31 & 0.30 \\
\hline Carbon content (wt.\%) & - & - & $<0.3$ & $<0.3$ & 1.1 \\
\hline
\end{tabular}

5 following the cuboctahedral model; ${ }^{\mathrm{c}}$ Determined from XRD; ${ }^{\mathrm{d}}$ see Table 1 for comparison.. 
Table 4. Carbon distribution within oxygenated compounds in the sorbitol transformation effluent. Operating conditions: $240^{\circ} \mathrm{C}, \mathrm{WHSV}=2 \mathrm{~h}^{-1}, \mathrm{M} / \mathrm{ZrO}_{2}+\mathrm{TiO}_{2}-\mathrm{WO}_{x}$ catalyst ( $\mathrm{M}=\mathrm{Pt}$, Pd or Ir).

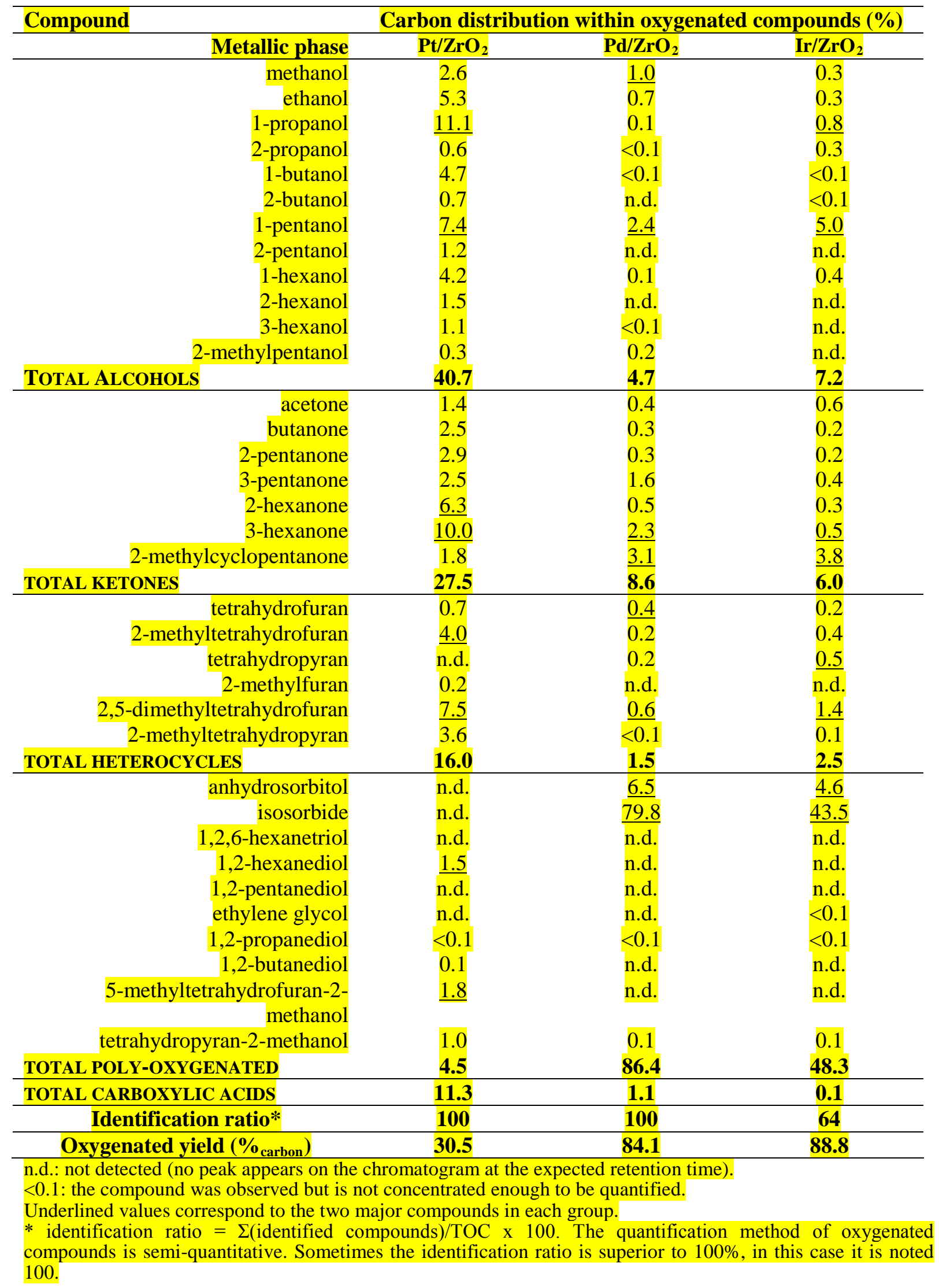


Table 5. Compositions of the $\mathrm{Pt} / \mathrm{ZrO}_{2}+\mathrm{TiO}_{2}-\mathrm{WO}_{\mathrm{x}}$ mechanical mixings.

Mechanical mixing $\mathrm{Pt} / \mathrm{ZrO}_{2} \mathrm{TiO}_{2}-\mathrm{WO}_{\mathrm{x}}$ Mass ratio Global Pt content Pt/acid catalyst mass (g) mass (g)

(wt.\%)

(wt.\%)

\begin{tabular}{|c|c|c|c|c|c|}
\hline $\begin{array}{c}\mathrm{Pt} / \mathrm{ZrO}_{2}: \mathrm{TiO}_{2}-\mathrm{WO}_{\mathrm{x}} \\
(0: 100)\end{array}$ & 0 & 4 & $0: 100$ & - & - \\
\hline $\begin{array}{c}\mathrm{Pt} / \mathrm{ZrO}_{2}: \mathrm{TiO}_{2}-\mathrm{WO}_{\mathrm{x}} \\
(11: 89)\end{array}$ & 0.5 & 4 & 11:89 & 0.24 & 0.27 \\
\hline $\begin{array}{c}\mathrm{Pt} / \mathrm{ZrO}_{2}: \mathrm{TiO}_{2}-\mathrm{WO}_{\mathrm{x}} \\
(20: 80)\end{array}$ & 1 & 4 & $20: 80$ & 0.44 & 0.55 \\
\hline $\begin{array}{c}\mathrm{Pt} / \mathrm{ZrO}_{2}: \mathrm{TiO}_{2}-\mathrm{WO}_{\mathrm{x}} \\
(33: 67)\end{array}$ & 2 & 4 & $33: 67$ & 0.73 & 1.10 \\
\hline
\end{tabular}


Table 6. Carbon distribution within oxygenated compounds in the sorbitol transformation effluent. Operating conditions: $240^{\circ} \mathrm{C}$, WHSV $=4 \mathrm{~h}^{-1}, \mathrm{Pt} / \mathrm{ZrO}_{2}+\mathrm{TiO}_{2}-\mathrm{WO}_{\mathrm{x}}$ catalyst with four different mass ratios.

\section{Compound Carbon distribution within oxygenated compounds (\%)}

\begin{tabular}{|c|c|c|c|c|}
\hline Mass ratio $\mathrm{Pt} / \mathrm{ZrO}_{2}$ :TiO $_{2}-\mathrm{WO}_{\mathrm{x}}$ & 0:100 & 11:89 & $20: 80$ & 33:67 \\
\hline methanol & 0.2 & 1.3 & 0.3 & 2.5 \\
\hline ethanol & n.d. & 0.8 & 0.5 & 4.6 \\
\hline 1-propanol & n.d. & 1.2 & 0.9 & 9.1 \\
\hline 2-propanol & 0.1 & 0.2 & $<0.1$ & 0.2 \\
\hline 1-butanol & n.d. & 0.5 & 0.5 & 4.3 \\
\hline 2-butanol & $<0.1$ & $<0.1$ & $<0.1$ & 0.3 \\
\hline 1-pentanol & $<0.1$ & $\underline{5.8}$ & $\underline{4.8}$ & $\underline{7.7}$ \\
\hline 2-pentanol & n.d. & $<0.1$ & 0.2 & 0.8 \\
\hline 1-hexanol & n.d. & $\underline{2.6}$ & $\underline{2.4}$ & $\underline{5.4}$ \\
\hline 2-hexanol & n.d. & $\overline{<0.1}$ & $\overline{\text { n.d. }}$ & $\overline{1.1}$ \\
\hline 3-hexanol & n.d. & $<0.1$ & 0.2 & 1.0 \\
\hline 2-methylpentanol & $<0.1$ & $<0.1$ & $<0.1$ & 0.7 \\
\hline Total alcohols & 0.4 & 12.7 & 10.0 & 37.9 \\
\hline acetone & 0.2 & 1.1 & 0.6 & 2.1 \\
\hline butanone & $<0.1$ & 0.4 & 1.1 & 1.9 \\
\hline 2-pentanone & $<0.1$ & 0.5 & 1.6 & 2.6 \\
\hline 3-pentanone & n.d. & 1.6 & 3.2 & 2.7 \\
\hline 2-hexanone & n.d. & 2.0 & $\underline{3.5}$ & $\underline{6.7}$ \\
\hline 3-hexanone & n.d. & $\underline{4.3}$ & $\underline{6.0}$ & $\overline{9.7}$ \\
\hline 2-methylcyclopentanone & $<0.1$ & $\overline{3.3}$ & $\overline{2.4}$ & $\overline{1.7}$ \\
\hline Total ketones & 0.3 & 13.1 & 18.5 & 27.5 \\
\hline tetrahydrofuran & n.d. & 0.2 & 0.1 & 0.6 \\
\hline 2-methyltetrahydrofuran & n.d. & 0.4 & $\underline{0.6}$ & $\underline{2.9}$ \\
\hline tetrahydropyran & n.d. & n.d. & $\overline{\text { n.d. }}$ & $\overline{\text { n.d. }}$ \\
\hline 2-methylfuran & n.d. & $<0.1$ & n.d. & $<0.1$ \\
\hline 2,5-dimethyltetrahydrofuran & 0.1 & 2.1 & 2.0 & $\underline{6.2}$ \\
\hline 2-methyltetrahydropyran & n.d. & $\underline{0.8}$ & $\overline{0.8}$ & $\overline{2.5}$ \\
\hline Total heterocycles & 0.1 & $\overline{3.6}$ & 3.5 & 12.3 \\
\hline anhydrosorbitol & 12.8 & $\underline{4.9}$ & $\underline{4.9}$ & n.d. \\
\hline isosorbide & $\overline{86.0}$ & $\underline{64.8}$ & $\overline{49.7}$ & n.d. \\
\hline 1,2,6-hexanetriol & $\overline{\text { n.d. }}$ & $\overline{\text { n.d. }}$ & $\overline{\text { n.d. }}$ & n.d. \\
\hline 1,2-hexanediol & n.d. & 0.3 & 0.9 & 6.0 \\
\hline 1,2-pentanediol & n.d. & n.d. & n.d. & n.d. \\
\hline ethylene glycol & $<0.1$ & $<0.1$ & n.d. & 0.2 \\
\hline 1,2-propanediol & n.d. & $<0.1$ & $<0.1$ & 1.4 \\
\hline 1,2-butanediol & n.d. & $<0.1$ & $<0.1$ & 0.5 \\
\hline $\begin{array}{l}\text { 5-methyltetrahydrofuran-2- } \\
\text { methanol }\end{array}$ & n.d. & $<0.1$ & $<0.1$ & $\underline{4.6}$ \\
\hline tetrahydropyran-2-methanol & n.d. & $<0.1$ & $<0.1$ & $\underline{2.7}$ \\
\hline Total poly-oxygenated & 98.8 & 70.1 & 55.8 & $\overline{15.4}$ \\
\hline Total carboxylic acids & 0.4 & 0.5 & 3.0 & 7.0 \\
\hline Identification ratio* & 100 & 100 & 90 & 100 \\
\hline Oxygenated yield ( $\left.\%_{\text {carbon }}\right)$ & 101.5 & 93.5 & 87.7 & 40.6 \\
\hline
\end{tabular}

n.d.: not detected (no peak appears on the chromatogram at the expected retention time); $<0.1$ : the compound was observed but is not concentrated enough to be quantified. Underlined values correspond to the two major compounds in each group.

\footnotetext{
a identification ratio $=\Sigma$ (identified compounds)/TOC x 100 . The quantification method of oxygenated compounds is semi-
} quantitative. Sometimes the identification ratio is superior to $100 \%$, in this case it is noted 100 . 


\section{Electronic supplementary information \\ Hydrocarbon fuel synthesis from sorbitol over bifunctional catalysts. Association of tungstated titania with platinum, palladium or iridium}

Léa Vilcocq, ${ }^{a}$ Amandine Cabiac, ${ }^{* a}$ Catherine Especel, ${ }^{b}$ Sylvie Lacombe ${ }^{a}$ and Daniel Duprez

${ }^{a}$ IFP Energies nouvelles, rond-point de l'échangeur de Solaize, BP 3, 69360 Solaize, France; Tel:+33(0) 4377020 00; E-mail: amandine.cabiac@ifpen.fr; sylvie.lacombe@ifpen.fr; vilcocq@uma.pt.

${ }^{b}$ C2MP (Institut de Chimie des Milieux et des Matériaux de Poitiers), Université de Poitiers, UMR 7285 CNRS, 4 rue Michel Brunet, 86022 Poitiers Cedex, France. Fax: +33 (0) 54945

34 99; Tel: +33 (0) 5494537 02; E-mail: daniel.duprez@univ-poitiers.fr; catherine.especel@univ-poitiers.fr. 


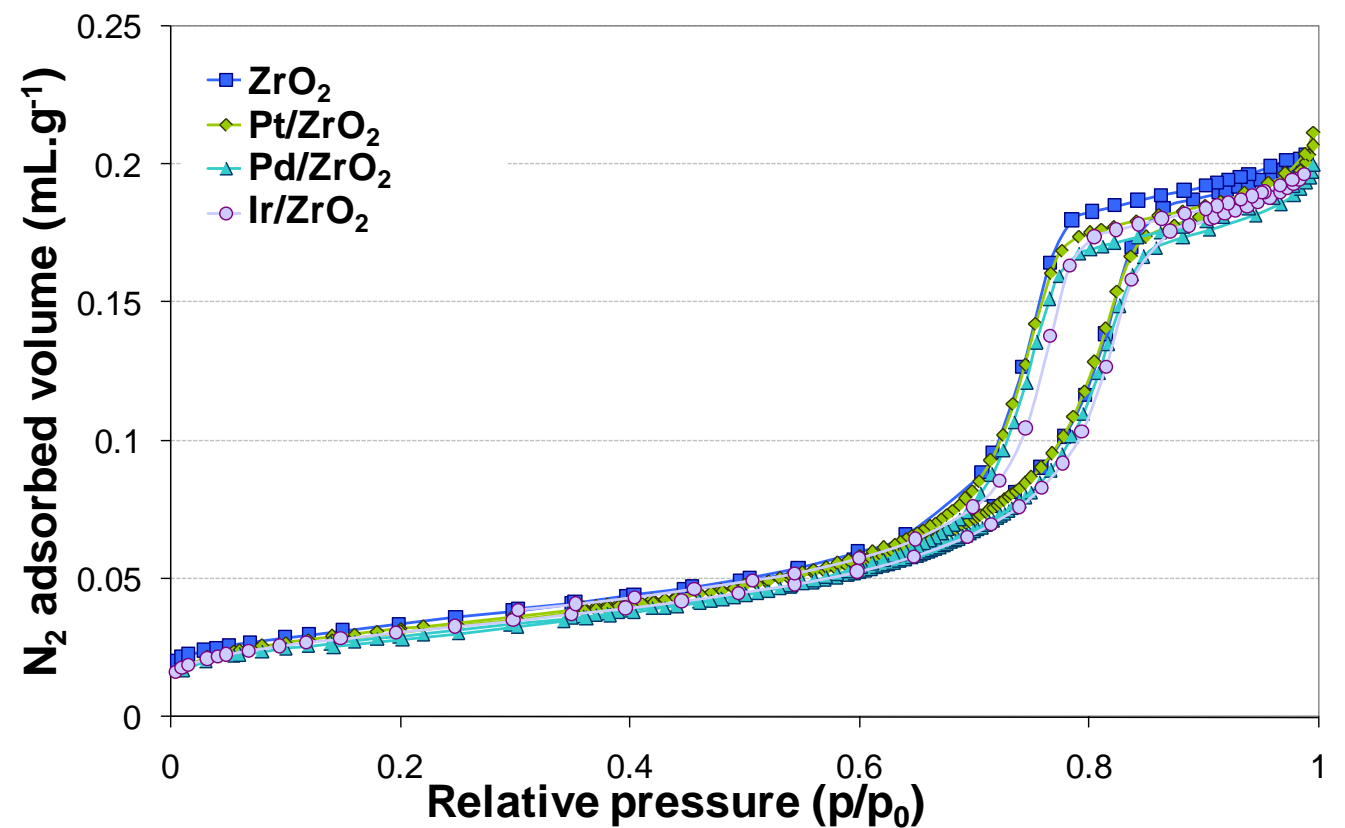

Figure S1. Nitrogen adsorption-desorption isotherms of monoclinic zirconia, fresh $\mathrm{Pt} / \mathrm{ZrO}_{2}, \mathrm{Pd} / \mathrm{ZrO}_{2}$ and $\mathrm{Ir} / \mathrm{ZrO} \mathrm{Z}_{2}$ catalysts.

Values calculated with the BJH method, on the desorption isotherm. 


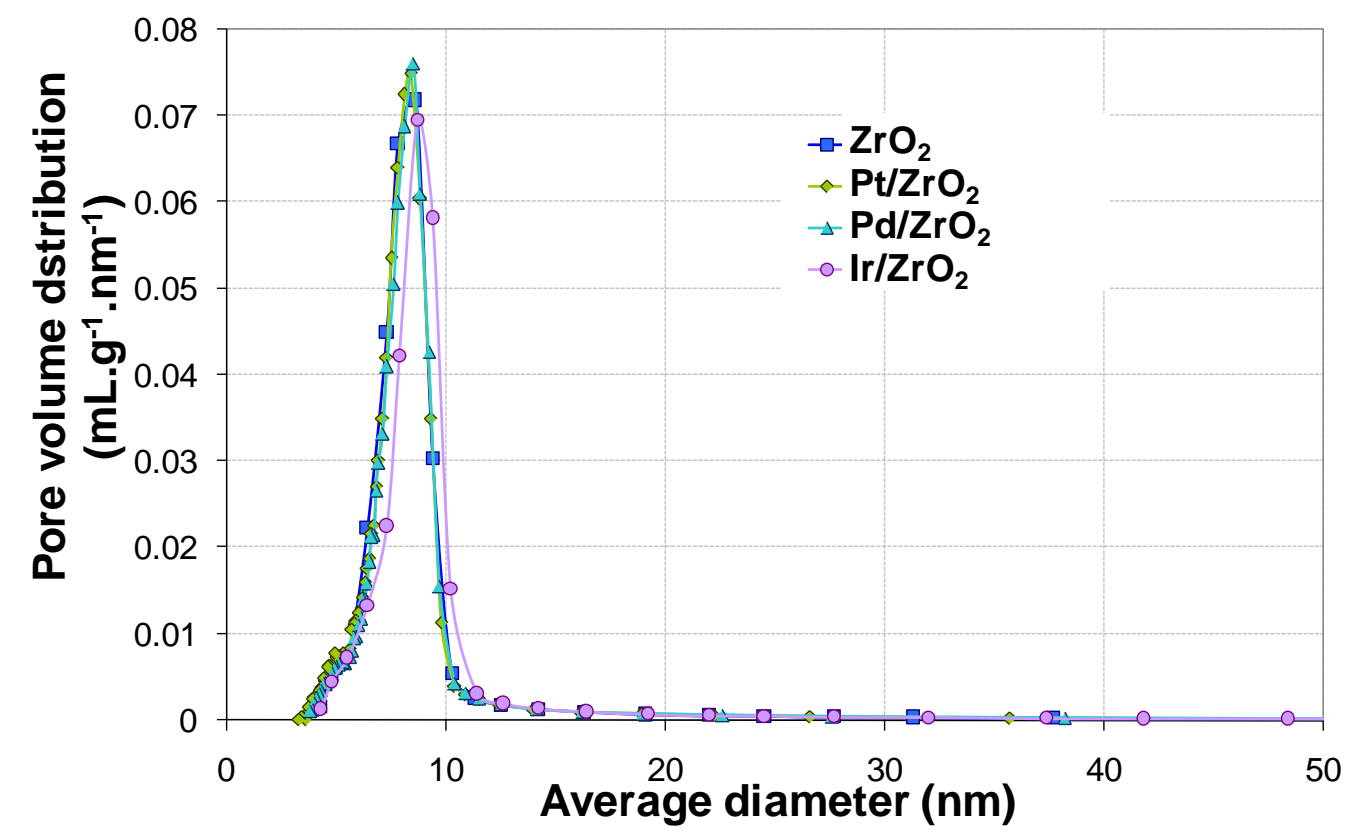

Figure S2. Pore size distribution of monoclinic zirconia, fresh $\mathrm{Pt} / \mathrm{ZrO}_{2}, \mathrm{Pd} / \mathrm{ZrO}_{2}$ and $\mathrm{Ir} / \mathrm{ZrO}$ catalysts. 


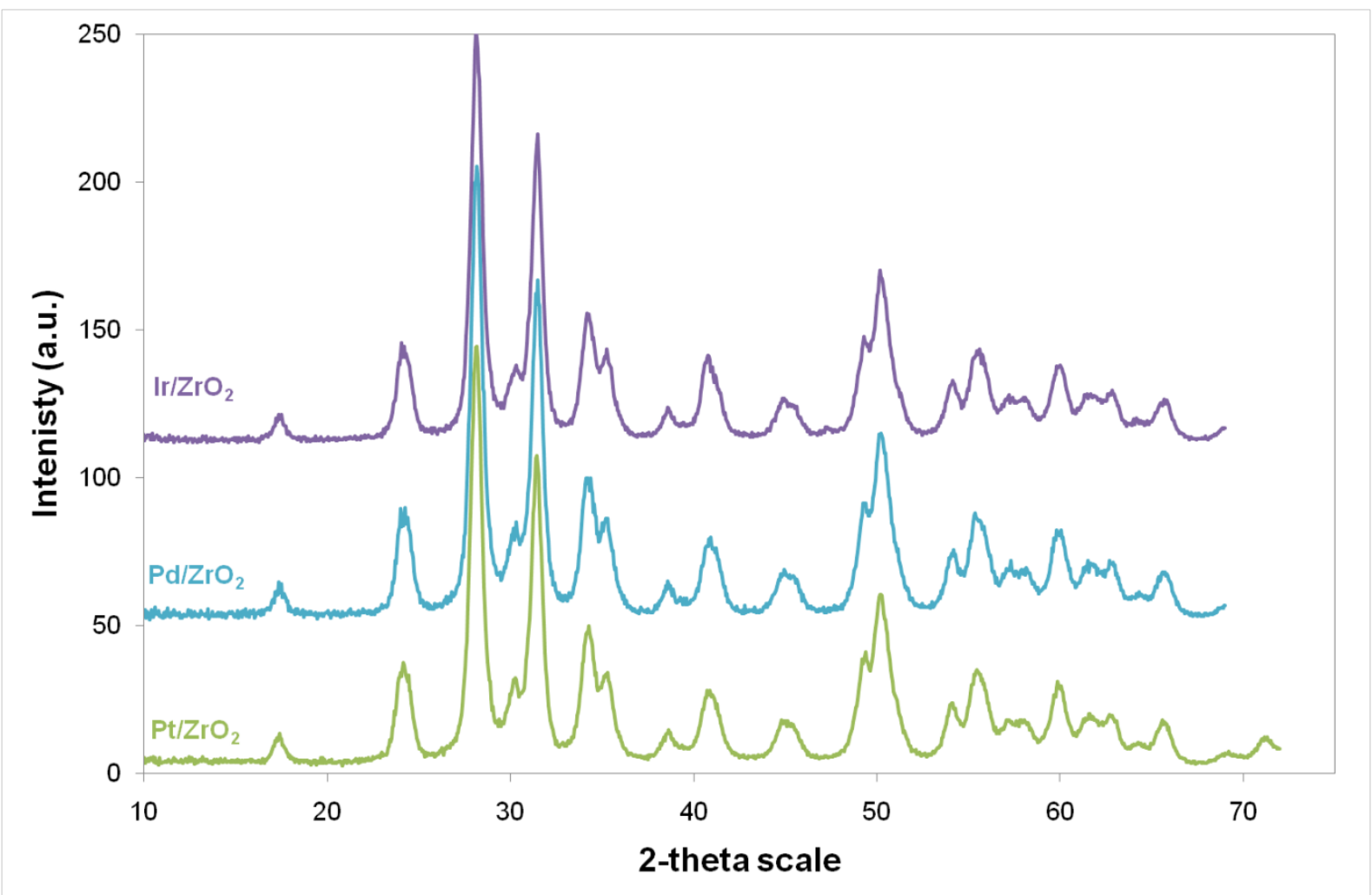

Figure S3. XRD patterns of fresh metallic catalysts. 


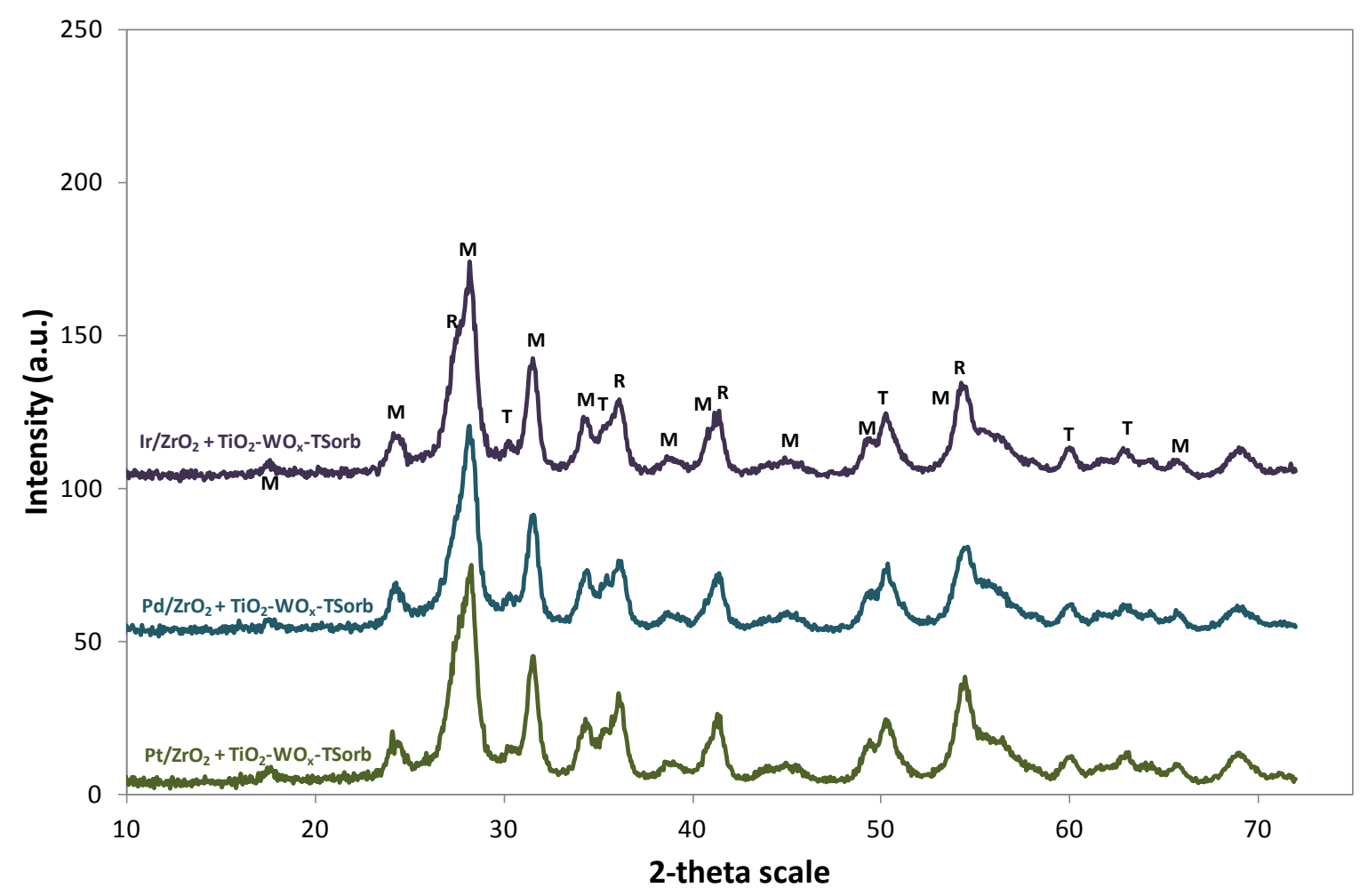

Figure S4. XRD diffractograms of mechanical mixtures $\mathrm{TiO}_{2}-\mathrm{WO}_{\mathrm{x}}+\mathrm{M} / \mathrm{ZrO}_{2}(\mathrm{M}=\mathrm{Pt}$, Pd or Ir $)$ after sorbitol transformation test.

Peaks attribution: $M=$ monoclinic zirconia; $T$ = tetragonal zirconia; $R=$ rutile titania . 


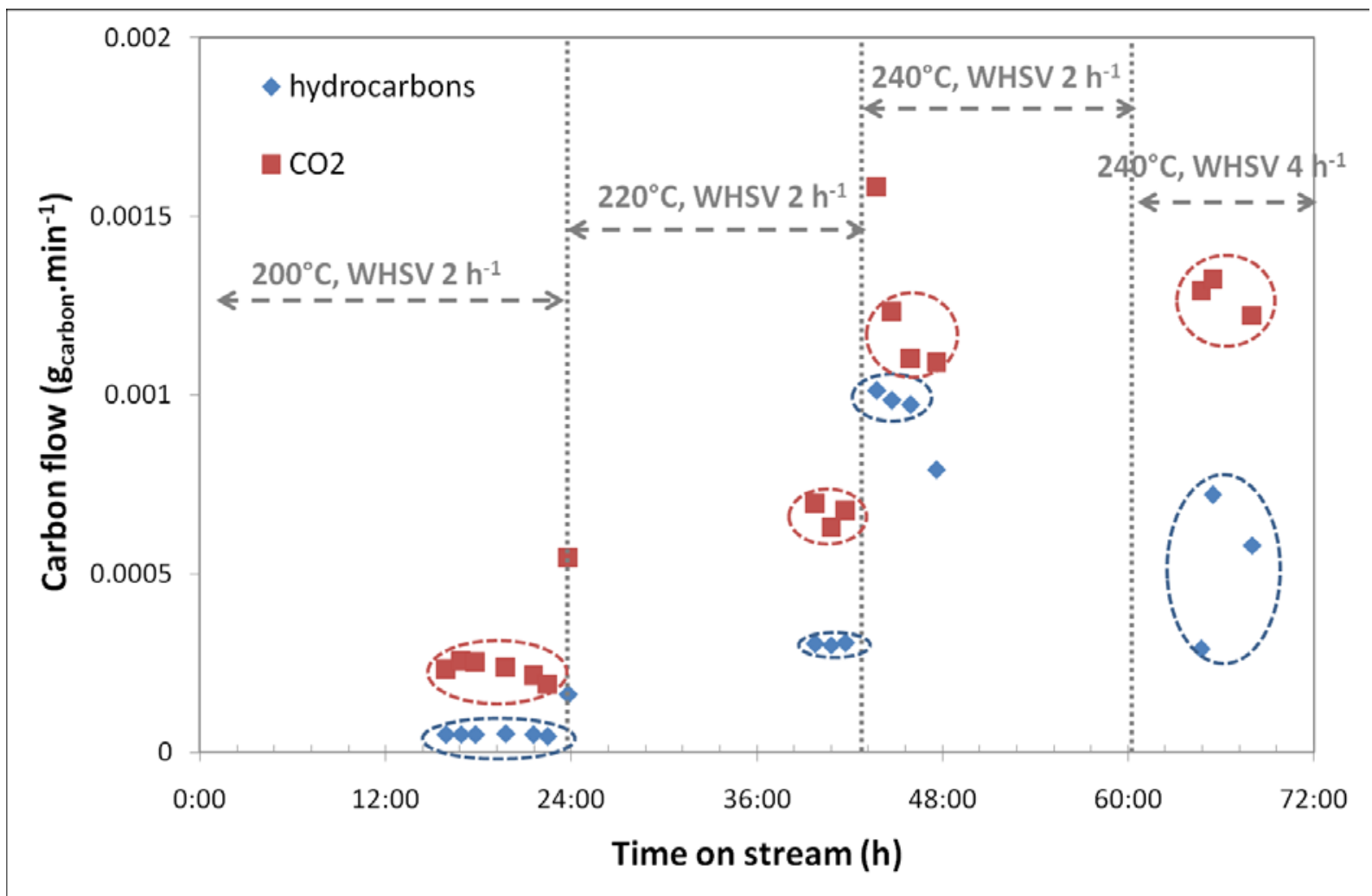

Figure S5. Carbon flows of gaseous products during the transformation of sorbitol over a bifunctional catalytic system $\mathrm{Pt} / \mathrm{ZrO}_{2}$ : $\mathrm{TiO}_{2}-\mathrm{WO}_{\mathrm{x}}$, mass ratio 33:67, as a function of time on stream. The points in circles were taken into account for the distribution and yield calculation. 
Table S6. Average carbon balance during sorbitol transformation test over various catalytic systems. The carbon balance is calculated from the sum of TOC, carbon in hydrocarbons and $\mathrm{CO}_{2}$, divided by the initial carbon content of sorbitol.

\begin{tabular}{lcc}
\hline Catalytic system & Mass ratio (g:g) & Carbon balance (\%) \\
\hline $\mathrm{TiO}_{2}-\mathrm{WO}_{\mathrm{x}}+\mathrm{Pt} / \mathrm{ZrO}_{2}$ & $4: 2$ & 78 \\
$\mathrm{TiO}_{2}-\mathrm{WO}_{\mathrm{x}}+\mathrm{Pd} / \mathrm{ZrO}_{2}$ & $4: 2$ & 103 \\
$\mathrm{TiO}_{2}-\mathrm{WO}_{\mathrm{x}}+\mathrm{Ir} / \mathrm{ZrO}_{2}$ & $4: 2$ & 92 \\
$\mathrm{TiO}_{2}-\mathrm{WO}_{\mathrm{x}}$ & - & 99 \\
$\mathrm{TiO}_{2}-\mathrm{WO}_{\mathrm{x}}+\mathrm{Pt} / \mathrm{ZrO}_{2}$ & $4: 1$ & 89 \\
$\mathrm{TiO}_{2}-\mathrm{WO}_{\mathrm{x}}+\mathrm{Pt} / \mathrm{ZrO}_{2}$ & $4: 0.5$ & 82 \\
\hline
\end{tabular}




\section{Figures}

Figure 1

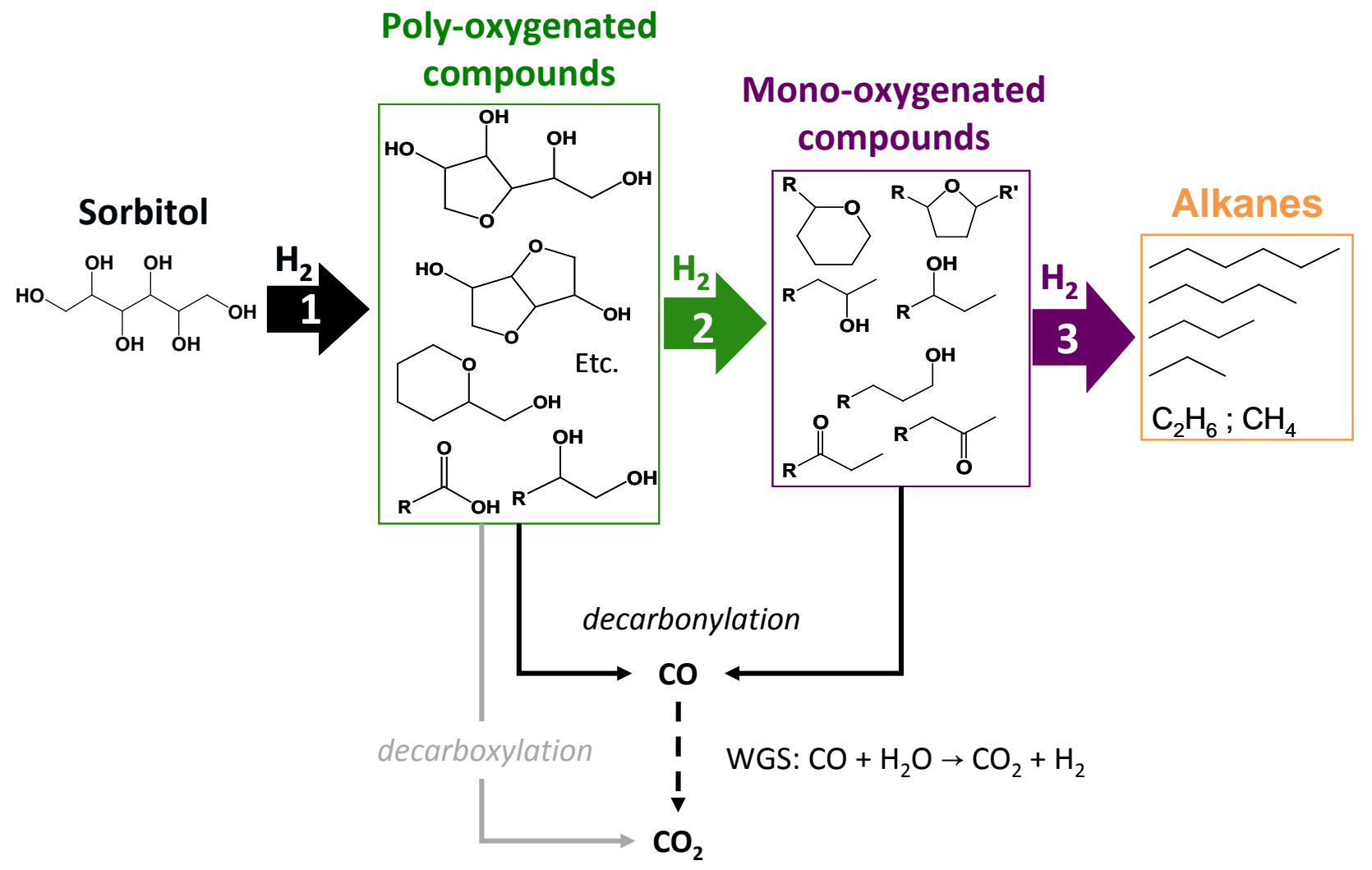


Figure 2

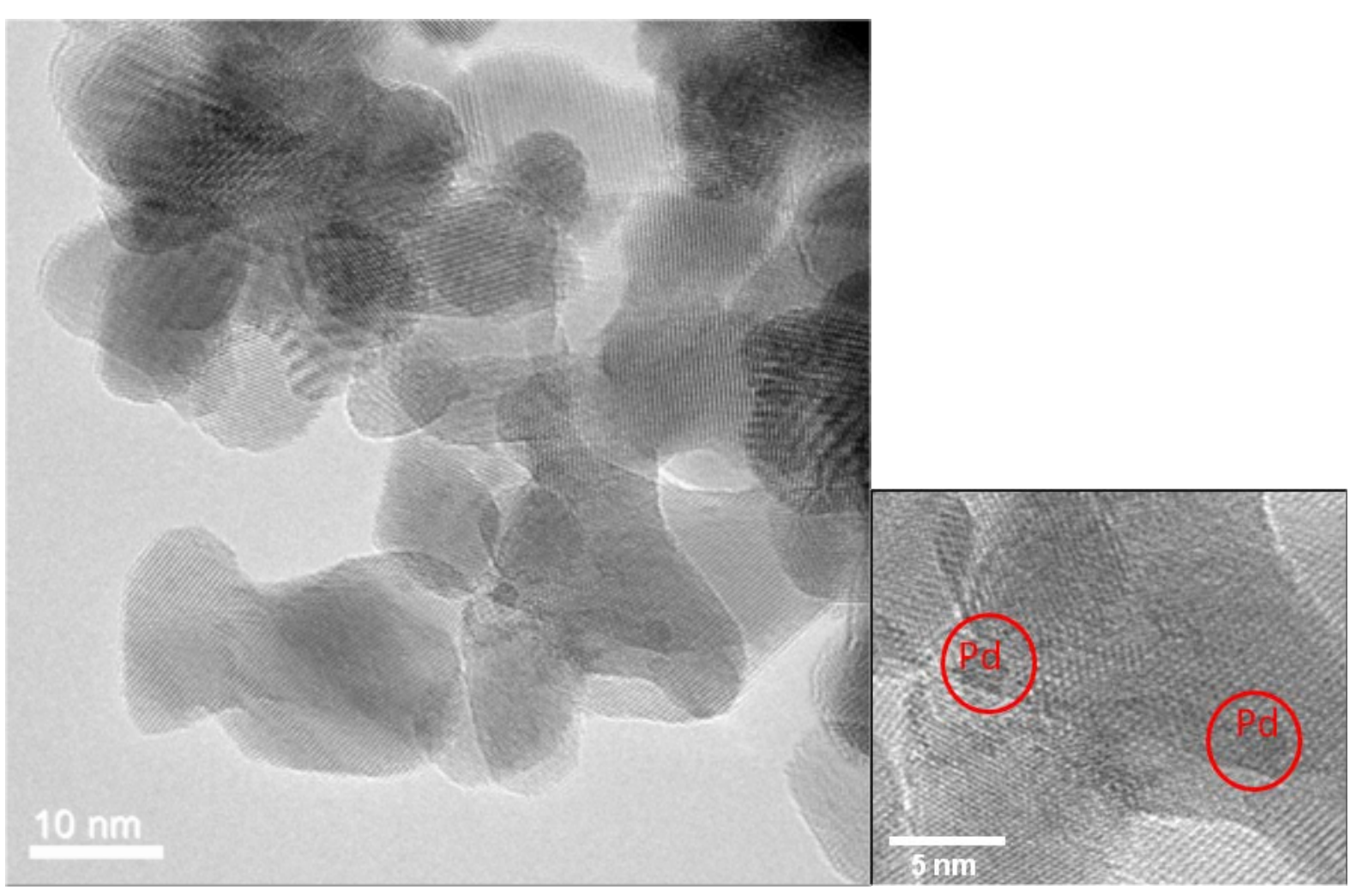


Figure 3

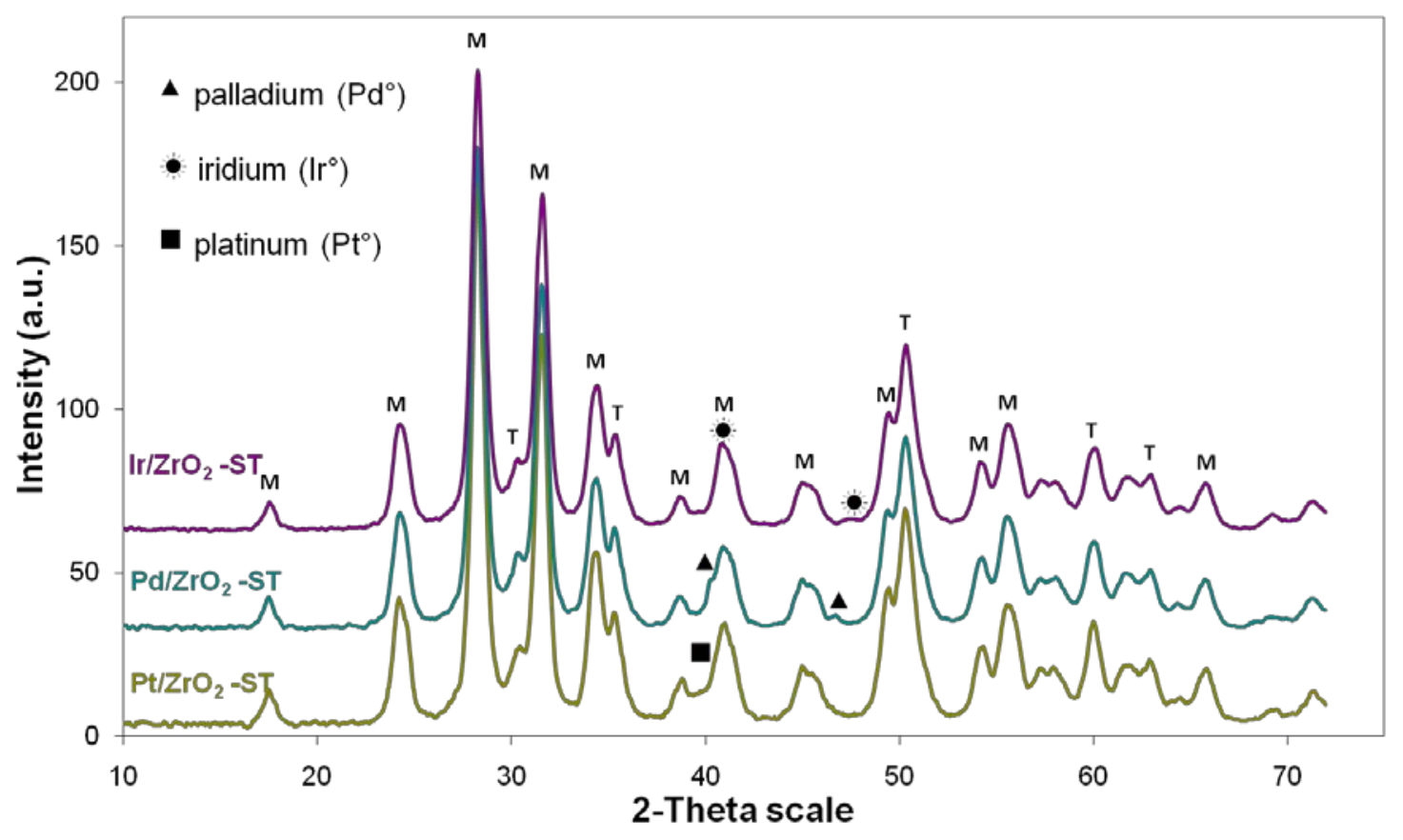


Figure 4

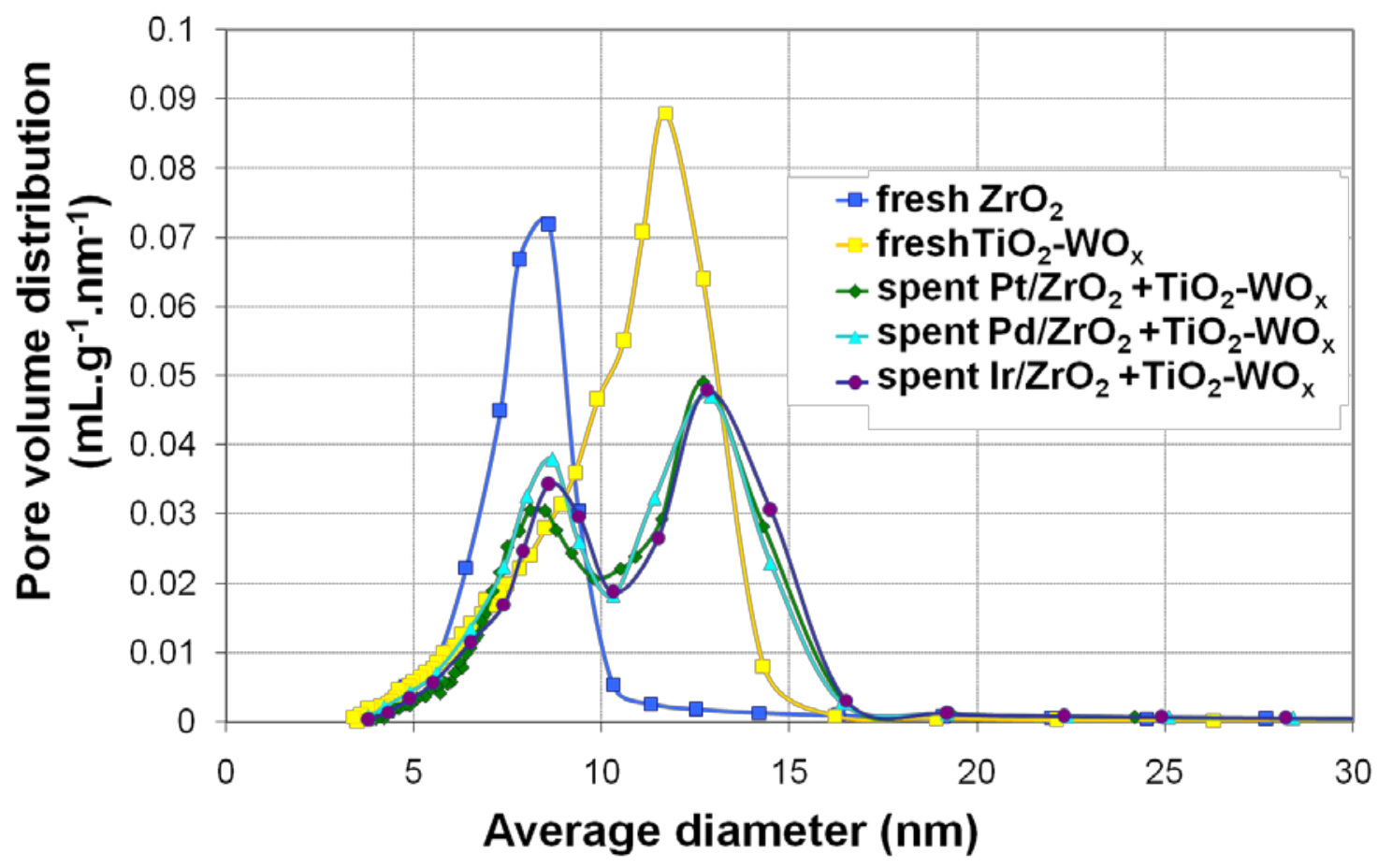


Figure 5

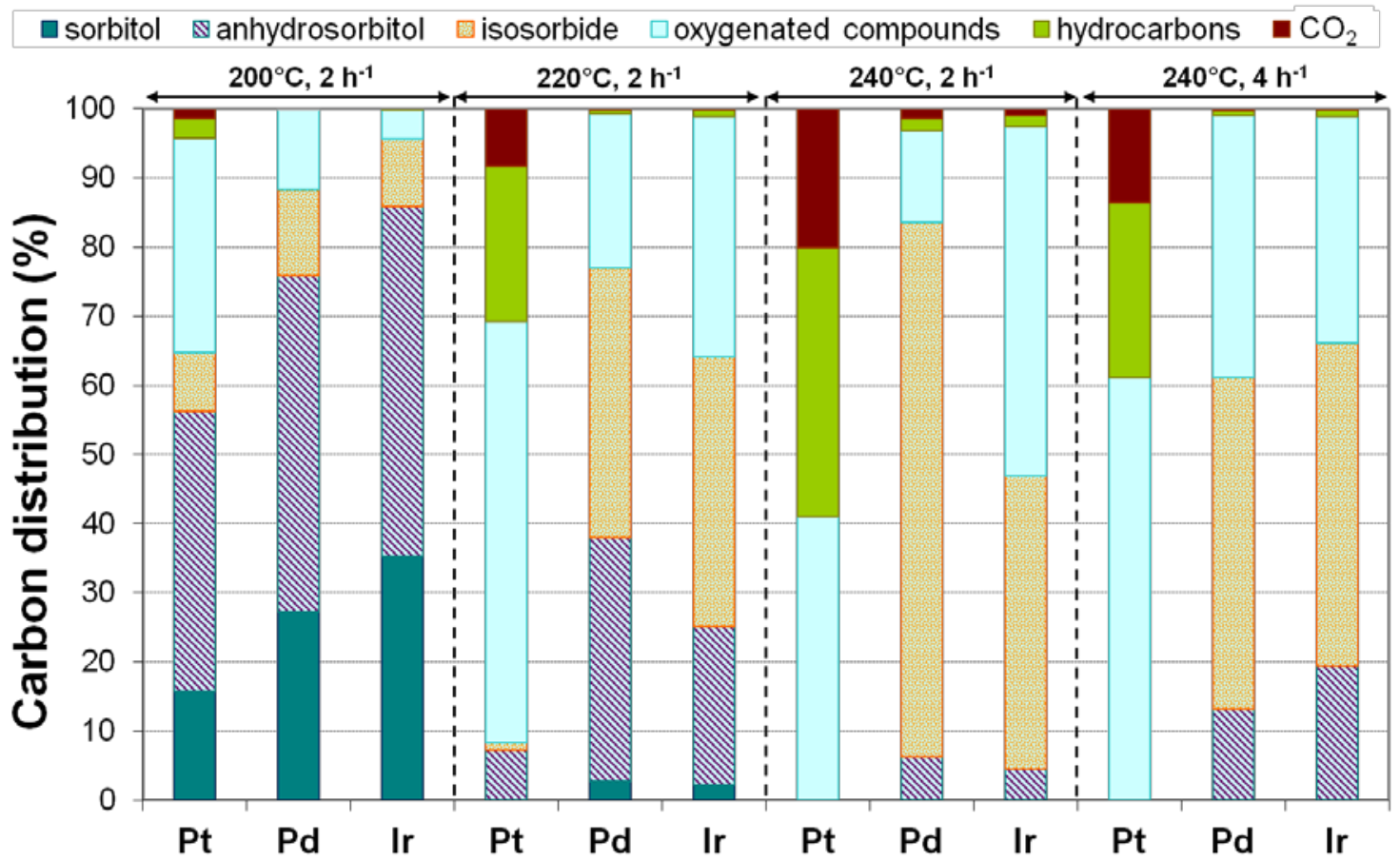


Figure 6

a)

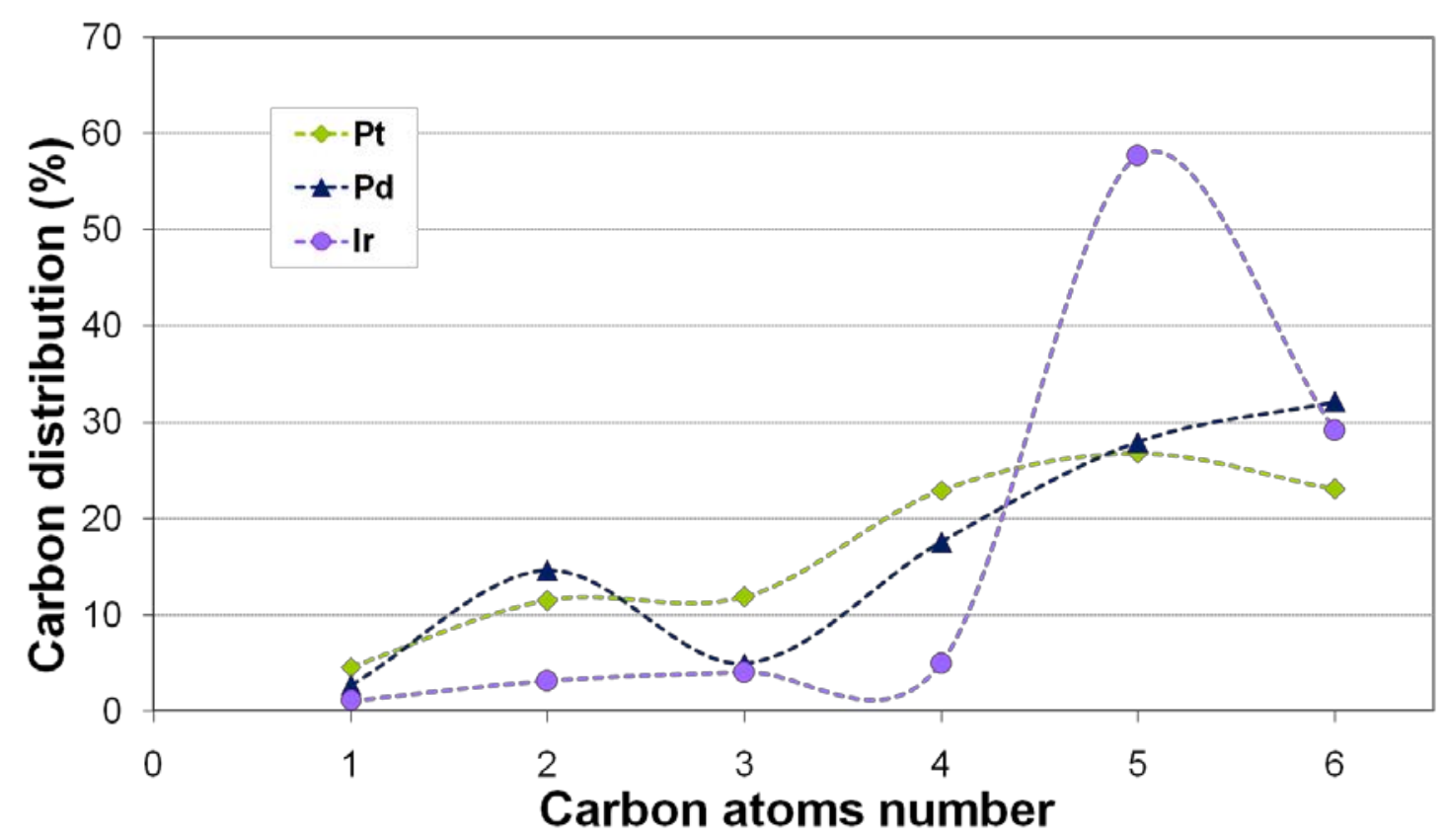

b)

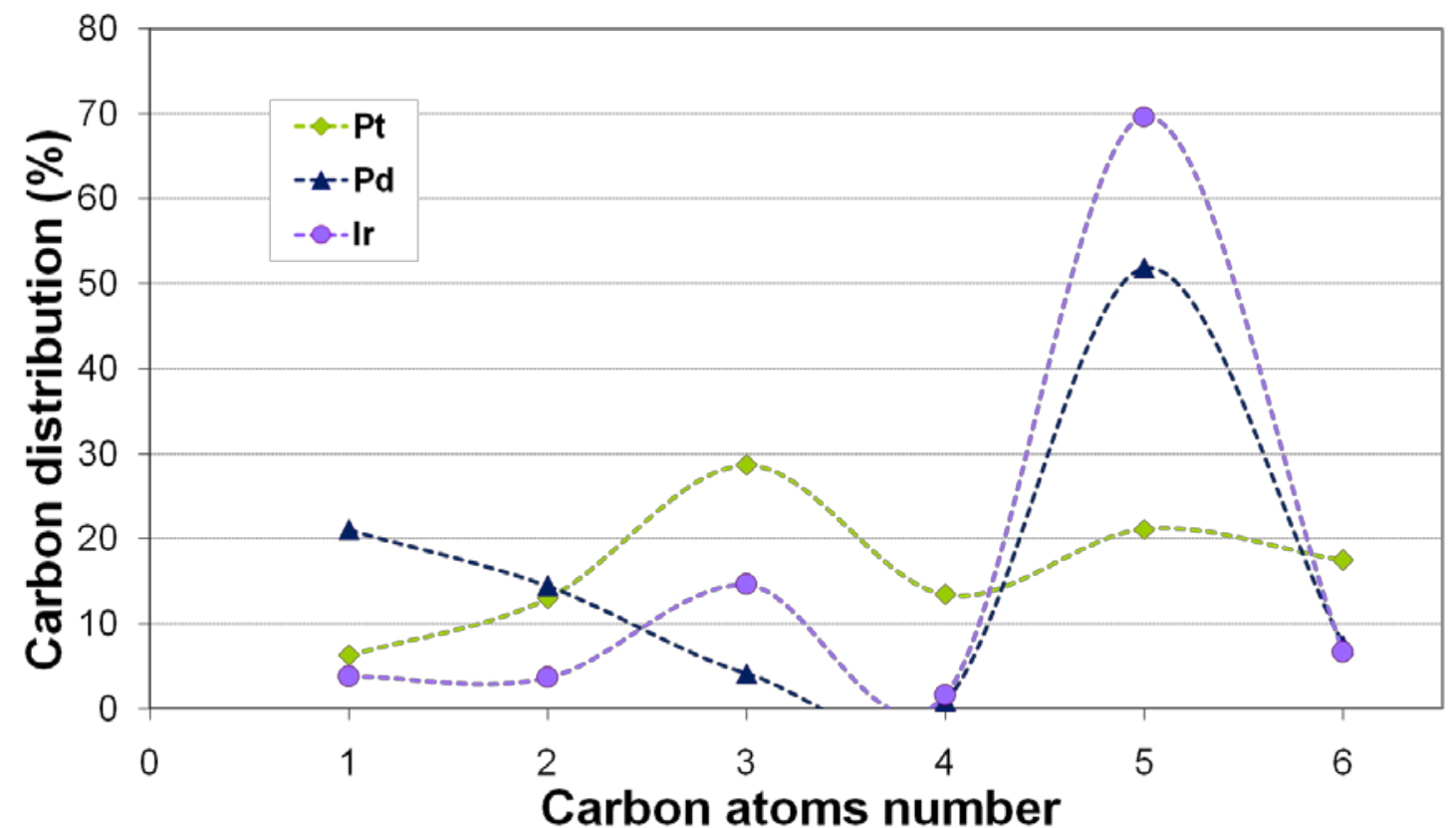


Figure 7

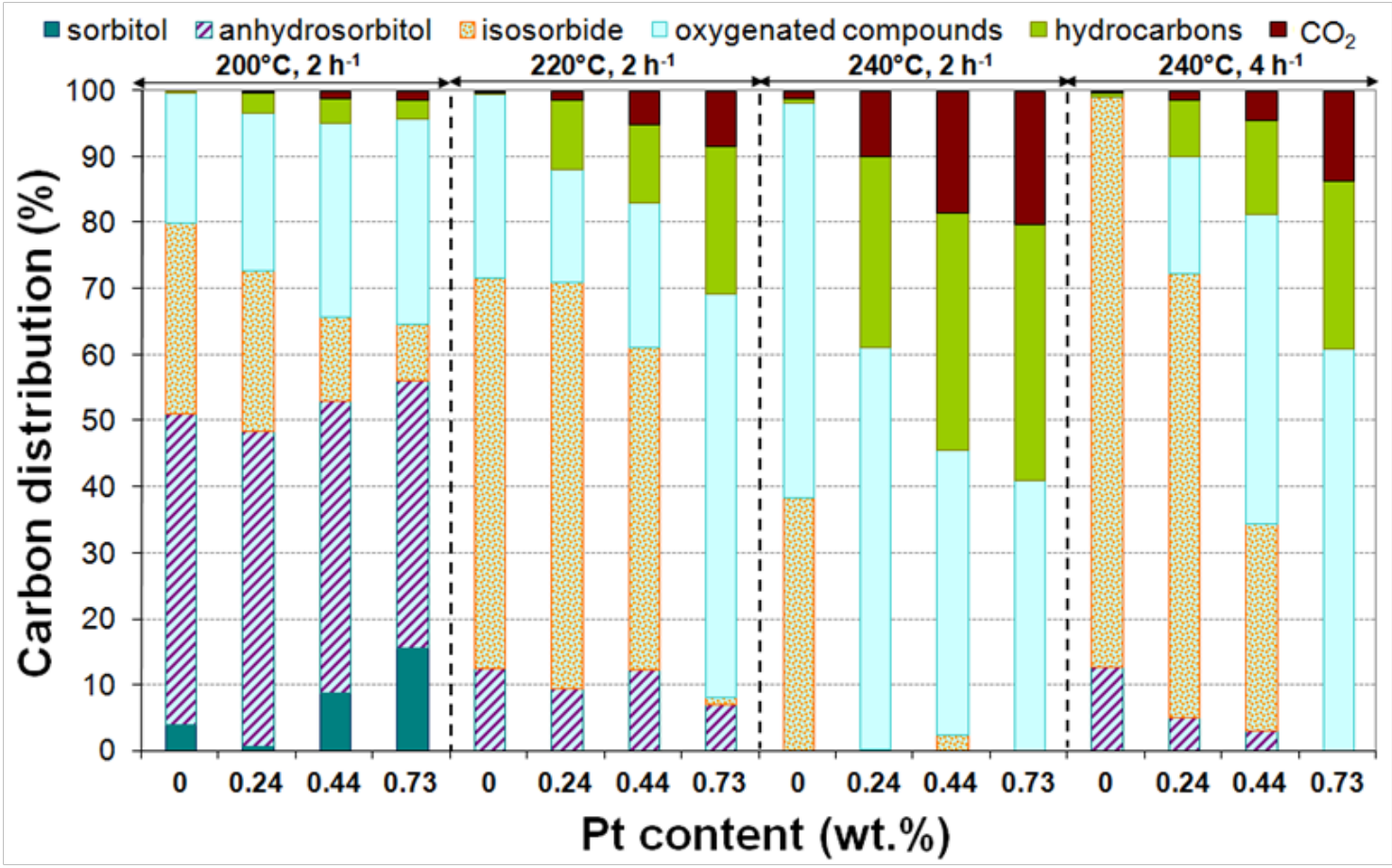


Figure 8

a)

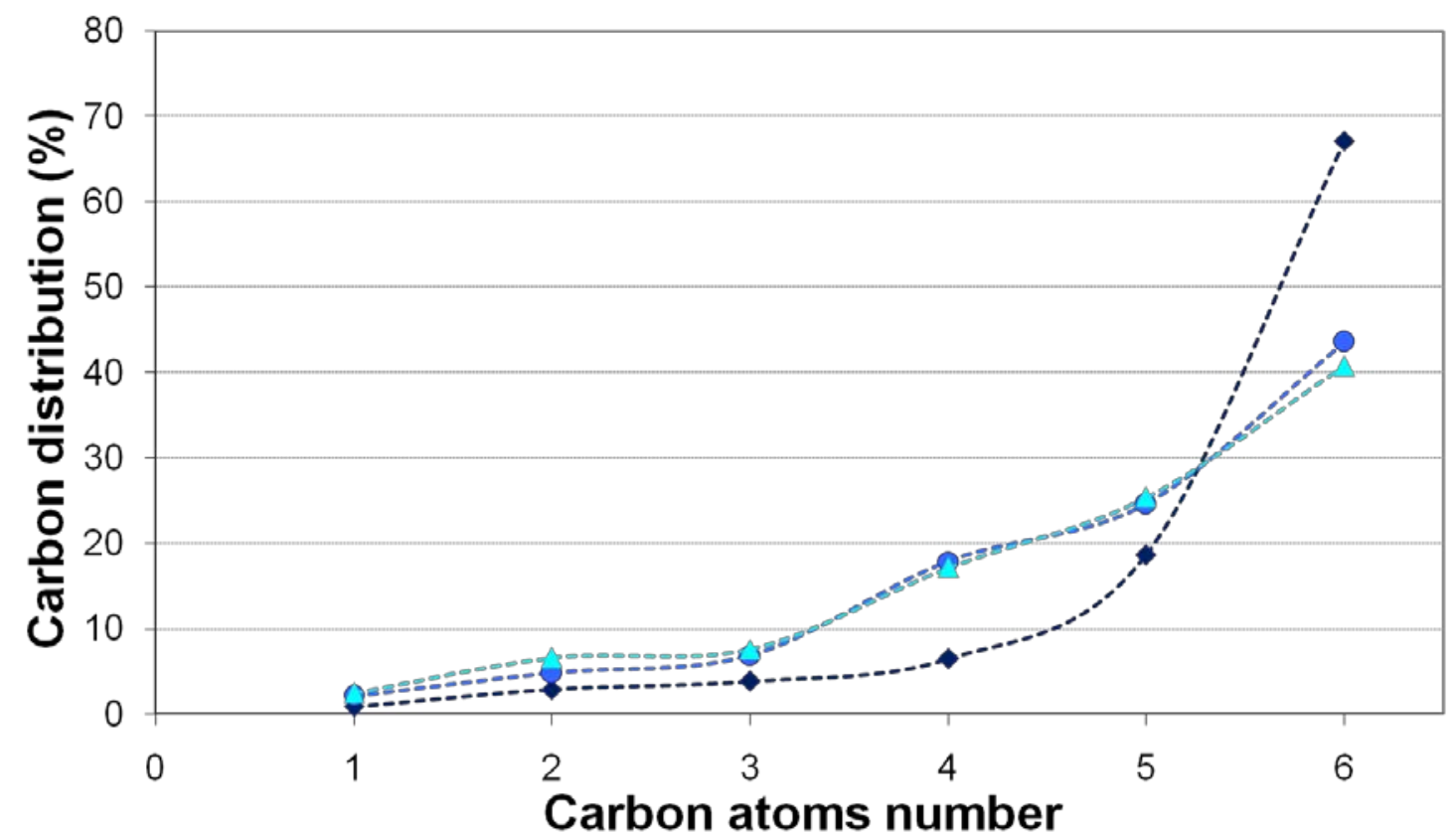

b)

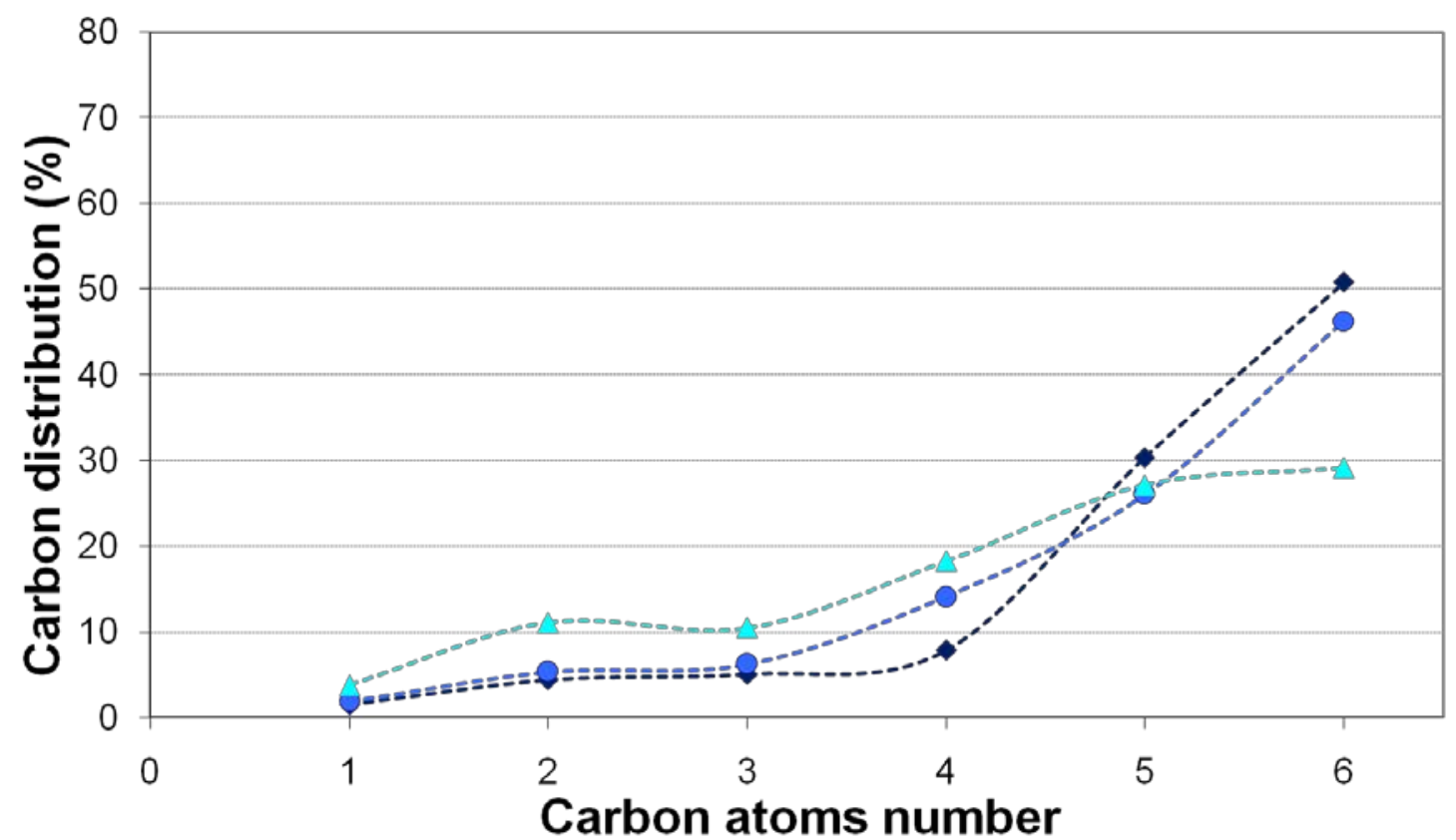


Figure 9

a)

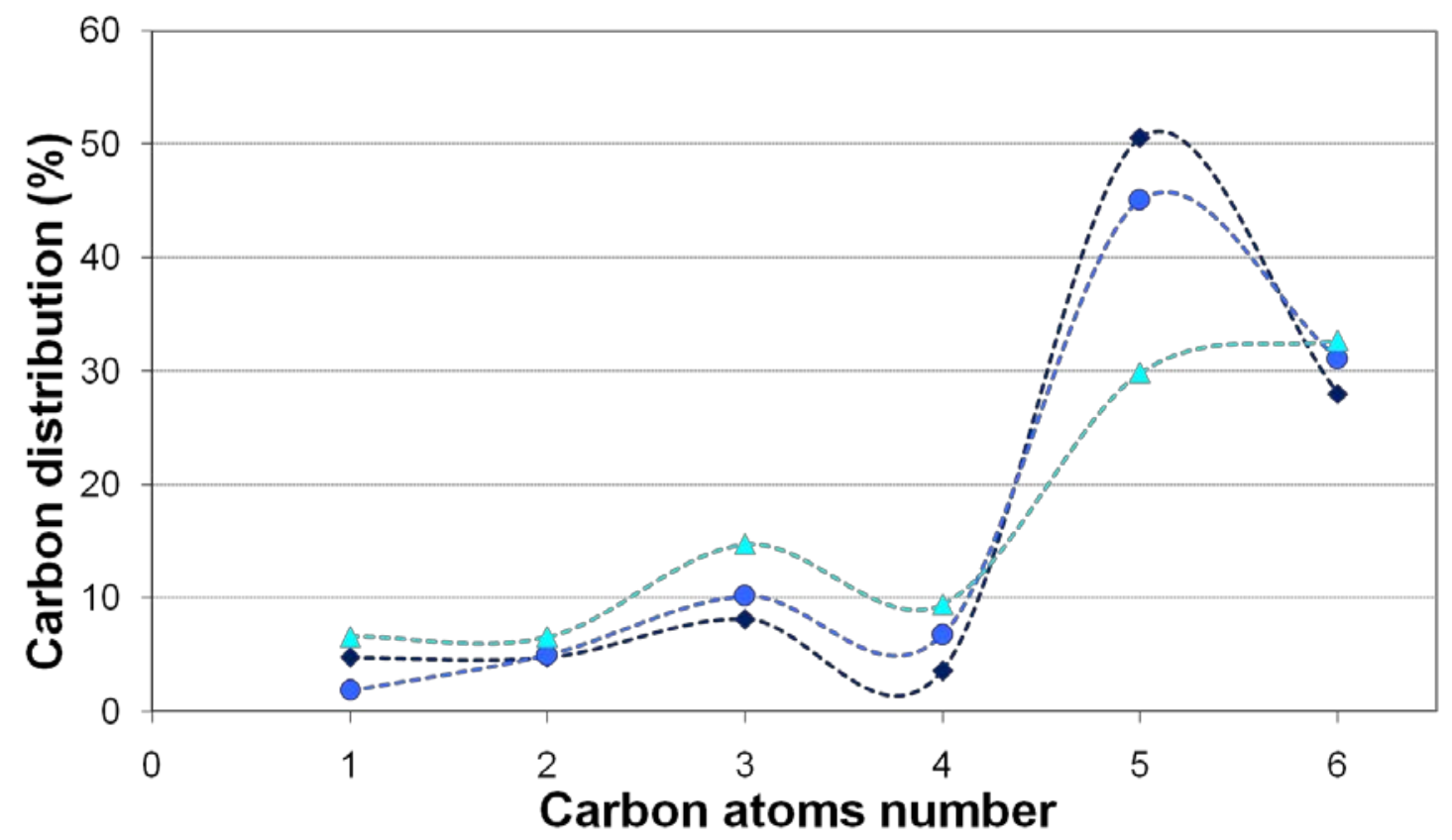

b)

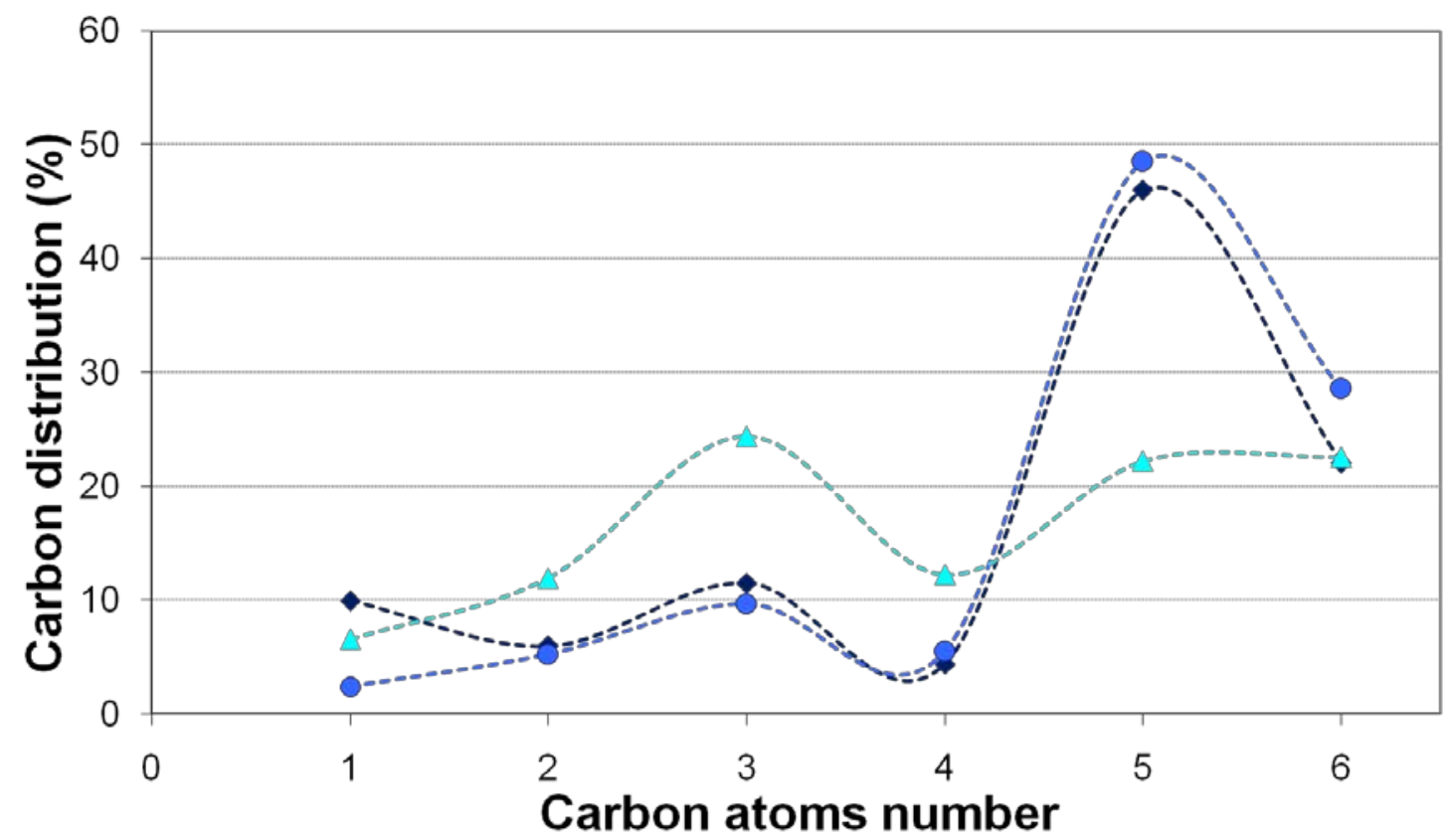

